\title{
Chiral Ruthenium PNNP Complexes of Non-Enolized 1,3-Dicarbonyl \\ Compounds: Acidity and Involvement in Asymmetric Michael Addition
}

Martin Althaus, Cristina Bonaccorsi, Antonio Mezzetti*, and Francesco Santoro

Department of Chemistry and Applied Biosciences, ETH Zürich, CH-8093 Zürich, Switzerland

\section{SUPPORTING INFORMATION}

General. Reactions with air- or moisture-sensitive materials were carried out under an argon atmosphere using Schlenk techniques or in a glove box. All solvents were distilled from an appropriate drying agent under argon prior to use $\left(\mathrm{CH}_{2} \mathrm{Cl}_{2}\right.$ and $\mathrm{CD}_{2} \mathrm{Cl}_{2}$ from $\mathrm{CaH}_{2}$, hexane from Na/benzophenone). Complex $\left[\mathrm{RuCl}_{2}(\mathrm{PNNP})\right]\left(\mathrm{PNNP}=(1 S, 2 S)-N, N^{\prime}\right.$-bis $\{o-($ diphenylphosphino)benzylidene \}-diaminocyclohexane) was prepared by a published procedure. ${ }^{1}{ }^{1} \mathrm{H}$, ${ }^{13} \mathrm{C},{ }^{31} \mathrm{P}$, and ${ }^{19} \mathrm{~F}$ NMR spectra were recorded on Bruker AVANCE spectrometers AC 200, DPX 250, and DPX 300. Multidimensional NMR spectra were recorded on a Bruker AVANCE spectrometer DPX 500. ${ }^{1} \mathrm{H}$ positive chemical shifts in ppm are downfield from tetramethylsilane. ${ }^{31} \mathrm{P}$ NMR spectra were referenced to external $85 \% \mathrm{H}_{3} \mathrm{PO}_{4}$, and ${ }^{19} \mathrm{~F} \mathrm{NMR}$ spectra were referenced to external $\mathrm{CFCl}_{3}$. Mass spectra were measured by the MS service of the Laboratorium für Organische Chemie (ETH Zürich). Optical rotations were measured using a Perkin Elmer 341 polarimeter with a $1 \mathrm{dm}$ cell. Elemental analyses were carried out by the Laboratory of Microelemental Analysis (ETH Zürich). Enantiomeric excesses were determined by HPLC using Agilent HPLC 1100 and HPLC 1050 Series systems. 


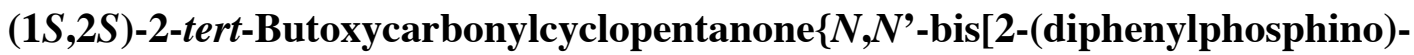

benzylidene]diaminocyclohexane\}ruthenium(II) Bis(hexafluorophosphate) (4a). Complex $\left[\mathrm{RuCl}_{2}(\mathrm{PNNP})\right](30 \mathrm{mg}, 36 \mu \mathrm{mol})$ and $\left(\mathrm{Et}_{3} \mathrm{O}\right) \mathrm{PF}_{6}(18.3 \mathrm{mg}, 74 \mu \mathrm{mol}, 2.04$ equiv) were dissolved in dry $\mathrm{CD}_{2} \mathrm{Cl}_{2}(0.8 \mathrm{~mL})$ in an NMR tube fitted with a Young-valve. The resulting solution was stirred at room temperature for $14 \mathrm{~h}$, and then, 2-tert-butoxycarbonylcyclopentanone (2) $(6.5 \mu \mathrm{L}, 36 \mu \mathrm{mol}, 1.0$ equiv) was added. The NMR spectroscopic analysis of the reaction solution indicated that $\mathbf{4 a}$ was formed in $92 \%$ purity (by integration of the ${ }^{31} \mathrm{P}$ NMR signals). The characterization of $\mathbf{4 a}$ was carried out on the crude reaction mixture by NMR spectroscopy.

${ }^{31} \mathbf{P}\left\{{ }^{1} \mathbf{H}\right\}$ NMR $\left(101 \mathrm{MHz}, \mathrm{CD}_{2} \mathrm{Cl}_{2}\right): \delta 61.2\left(d, 1 \mathrm{P}, J_{\mathrm{P}, \mathrm{P}}{ }^{\prime}=29.1 \mathrm{~Hz}\right), 51.3\left(d, 1 \mathrm{P}, J_{\mathrm{P}, \mathrm{P}}=29.1\right.$ $\mathrm{Hz}),-144.3\left(\right.$ sept, $\left.2 \mathrm{P}, J_{\mathrm{P}, \mathrm{F}}=711 \mathrm{~Hz}, P \mathrm{~F}_{6}\right)$.

${ }^{1} \mathbf{H}$ NMR $\left(250 \mathrm{MHz}, \mathrm{CD}_{2} \mathrm{Cl}_{2},\right): \delta 9.03\left(d, 1 \mathrm{H}, J_{\mathrm{P}, \mathrm{H}}=9.0 \mathrm{~Hz}, H^{b} \mathrm{C}=\mathrm{N}\right), 8.83\left(s, 1 \mathrm{H}, H^{b} \mathrm{C}=\mathrm{N}\right)$, $7.94\left(d d, 1 \mathrm{H}, J_{\mathrm{H}, \mathrm{H}}=7.2,3.2 \mathrm{~Hz}\right.$, benzylidene- $\left.H^{c}\right), 7.89\left(d d, 1 \mathrm{H}, J_{\mathrm{H}, \mathrm{H}}=7.4,4.3 \mathrm{~Hz}\right.$, benzylidene- $\left.H^{c^{\prime}}\right), 7.8-6.8(m, 25 \mathrm{H}$, arom. $), 6.72\left(d d, 1 \mathrm{H}, J_{\mathrm{H}, \mathrm{H}}=8.8,8.8 \mathrm{~Hz}\right.$, arom. $), 3.78$ $\left(d d, 1 \mathrm{H}, J_{\mathrm{H}, \mathrm{H}}=11.0,9.1 \mathrm{~Hz}, \mathrm{C}(\mathrm{O}) \mathrm{C} H^{d} \mathrm{COO}\right), 3.40-3.32\left(m, 1 \mathrm{H}, H^{a} \mathrm{C}-\mathrm{N}\right), 3.00(b r d, 1 \mathrm{H}$, $\left.J_{\mathrm{H}, \mathrm{H}}=11.4 \mathrm{~Hz}, \mathrm{CH} \mathrm{H}^{\prime}\right), 2.52-2.42\left(m, 2 \mathrm{H}, \mathrm{CH}_{2}\right), 2.42-2.35\left(m, 1 \mathrm{H}, H^{a^{\prime}} \mathrm{C}-\mathrm{N}\right), 1.96(b r d, 1$ $\left.\mathrm{H}, J_{\mathrm{H}, \mathrm{H}}=13.6 \mathrm{~Hz}, \mathrm{CH} \mathrm{H}^{\prime}\right), 1.92-1.83\left(m, 1 \mathrm{H}, \mathrm{CH} \mathrm{H}^{\prime}\right), 1.67-1.62\left(m, 2 \mathrm{H}, \mathrm{CH}_{2}\right), 1.46-1.37$ ( $\left.m, 1 \mathrm{H}, \mathrm{CH} \mathrm{H}^{\prime}\right), 1.36-1.25$ (m, $\left.3 \mathrm{H}, \mathrm{CH} \mathrm{H}^{\prime}\right), 1.25-1.16\left(m, 1 \mathrm{H}, \mathrm{CH} \mathrm{H}^{\prime}\right), 1.21(s, 9 \mathrm{H}$, $\left.\mathrm{C}\left(\mathrm{CH}_{3}{ }^{e}\right)_{3}\right), 1.00-0.90\left(m, 1 \mathrm{H}, \mathrm{CH} \mathrm{H}^{\prime}\right), 0.82-0.71\left(m, 1 \mathrm{H}, \mathrm{CH} \mathrm{H}^{\prime}\right)$.

${ }^{13} \mathbf{C}\left\{{ }^{1} \mathbf{H}\right\}$ NMR $\left(126 \mathrm{MHz}, \mathrm{CD}_{2} \mathrm{Cl}_{2},\right): \delta 227.3\left(C^{i}=\mathrm{O}\right), 175.2\left(C^{j} \mathrm{OO}\right), 170.9\left(d, J_{\mathrm{C}, \mathrm{P}}=4.8 \mathrm{~Hz}\right.$, $C=\mathrm{N}), 168.6\left(d, J_{\mathrm{C}, \mathrm{P}}=4.9 \mathrm{~Hz}, C=\mathrm{N}\right), 139.6-125.5(36 \mathrm{C}$, arom. $), 90.8\left(\mathrm{OC}_{\left.\left(\mathrm{CH}_{3}\right)_{3}\right), 78.0}\right.$ $\left(C^{a}-\mathrm{N}\right), \quad 70.0\left(C^{a}-\mathrm{N}\right), \quad 55.5\left(\mathrm{C}(\mathrm{O}) C^{d} \mathrm{HCOO}\right), \quad 32.2 \quad\left(C \mathrm{H}_{2}\right), \quad 31.5 \quad\left(C \mathrm{H}_{2}\right), \quad 28.1$ $\left(\mathrm{C}(\mathrm{O}) \mathrm{CH}_{2} \mathrm{CH}_{2} C^{k} \mathrm{H}_{2}\right), 27.9\left(\mathrm{C}\left(\mathrm{CH}_{3}\right)_{3}\right), 27.2\left(\mathrm{CH}_{2}\right), 24.9\left(\mathrm{CH}_{2}\right), 24.1\left(\mathrm{CH}_{2}\right), 19.5\left(\mathrm{CH}_{2}\right)$. 
Figure S1. Expansion of the one-bond ${ }^{13} \mathrm{C}-{ }^{1} \mathrm{H}$ HMQC NMR spectrum of $4 \mathbf{a}$, showing $\mathrm{H}^{\mathrm{d}}$ bound to $\mathrm{C}^{\mathrm{d}}$ in the coordinated $\beta$-ketoester 2 , and the correlation of $\mathrm{H}^{\mathrm{a}}-\mathrm{C}^{\mathrm{a}}$ and $\mathrm{H}^{\mathrm{a}}-\mathrm{C}^{\mathrm{a}}$ in the PNNP ligand.

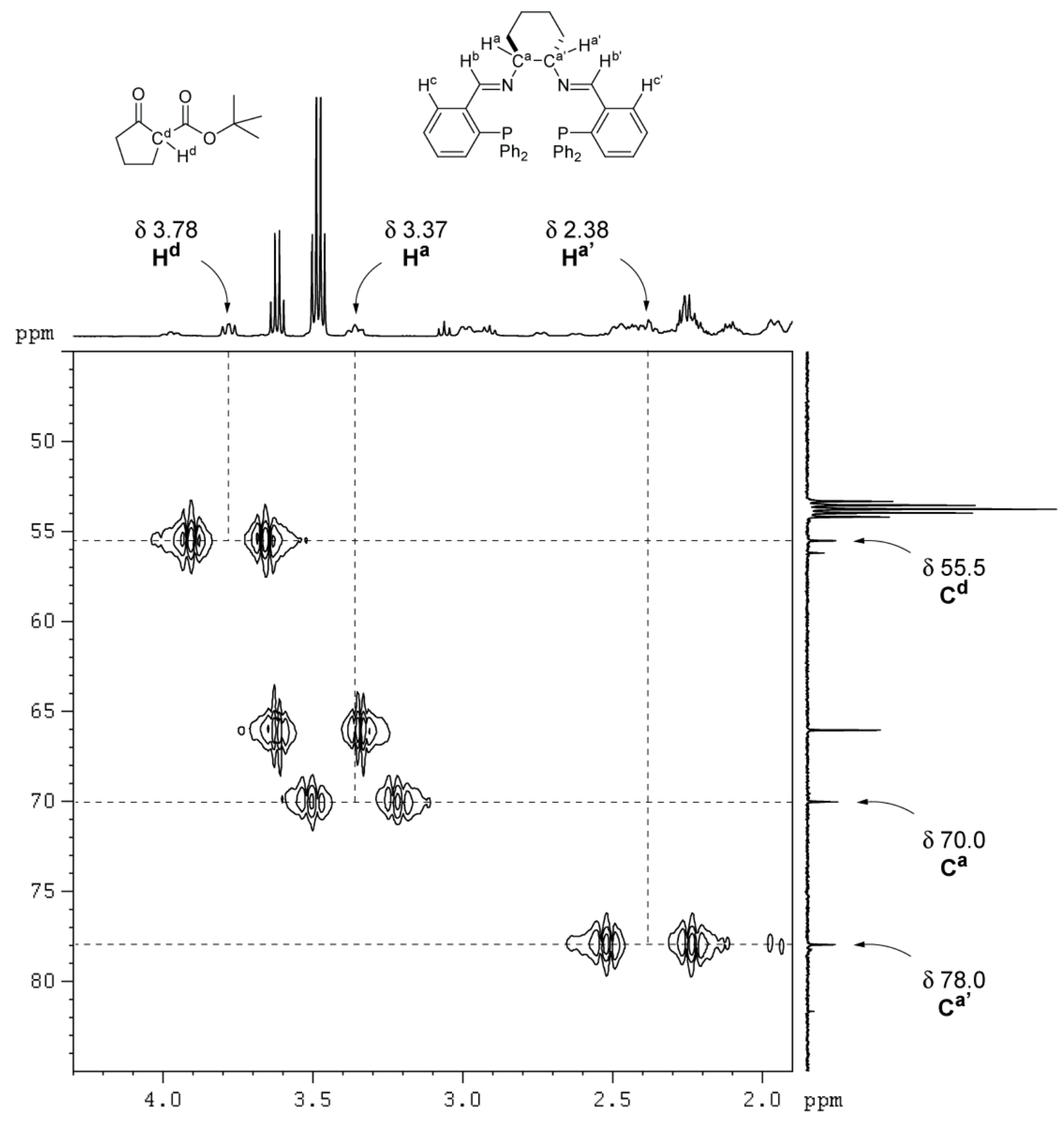


Figure S2. Expansion of the long-range ${ }^{13} \mathrm{C}-{ }^{1} \mathrm{H}$ HMQC NMR spectrum of 4a. The dashed lines highlight the correlations of $\mathrm{H}^{\mathrm{d}}$ in $\beta$-ketoester 2 with the adjacent $\mathrm{C}^{\mathrm{i}}, \mathrm{C}^{\mathrm{j}}$, and $\mathrm{C}^{\mathrm{k}}$.

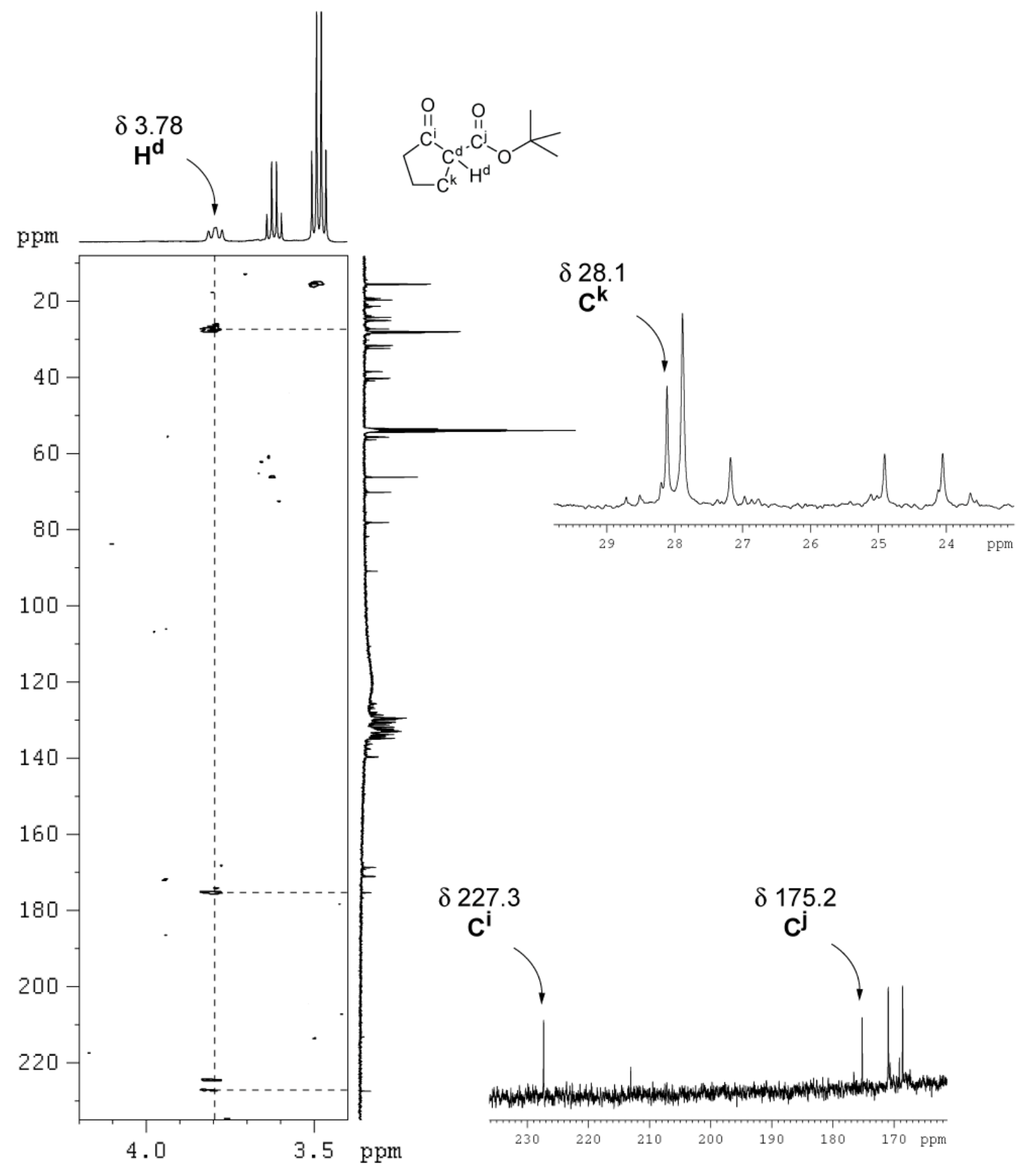


Figure S3. ${ }^{1} \mathrm{H}-{ }^{1} \mathrm{H}$ NOESY NMR spectrum of $\mathbf{4 a}$. The dashed lines highlight the NOE contacts between the $\alpha$-proton of $\beta$-ketoester $2\left(\mathrm{H}^{\mathrm{d}}\right)$ and $\mathrm{H}^{\mathrm{a}}, \mathrm{H}^{\mathrm{b}}$, and $\mathrm{H}^{\mathrm{c}}$ of the PNNP ligand.
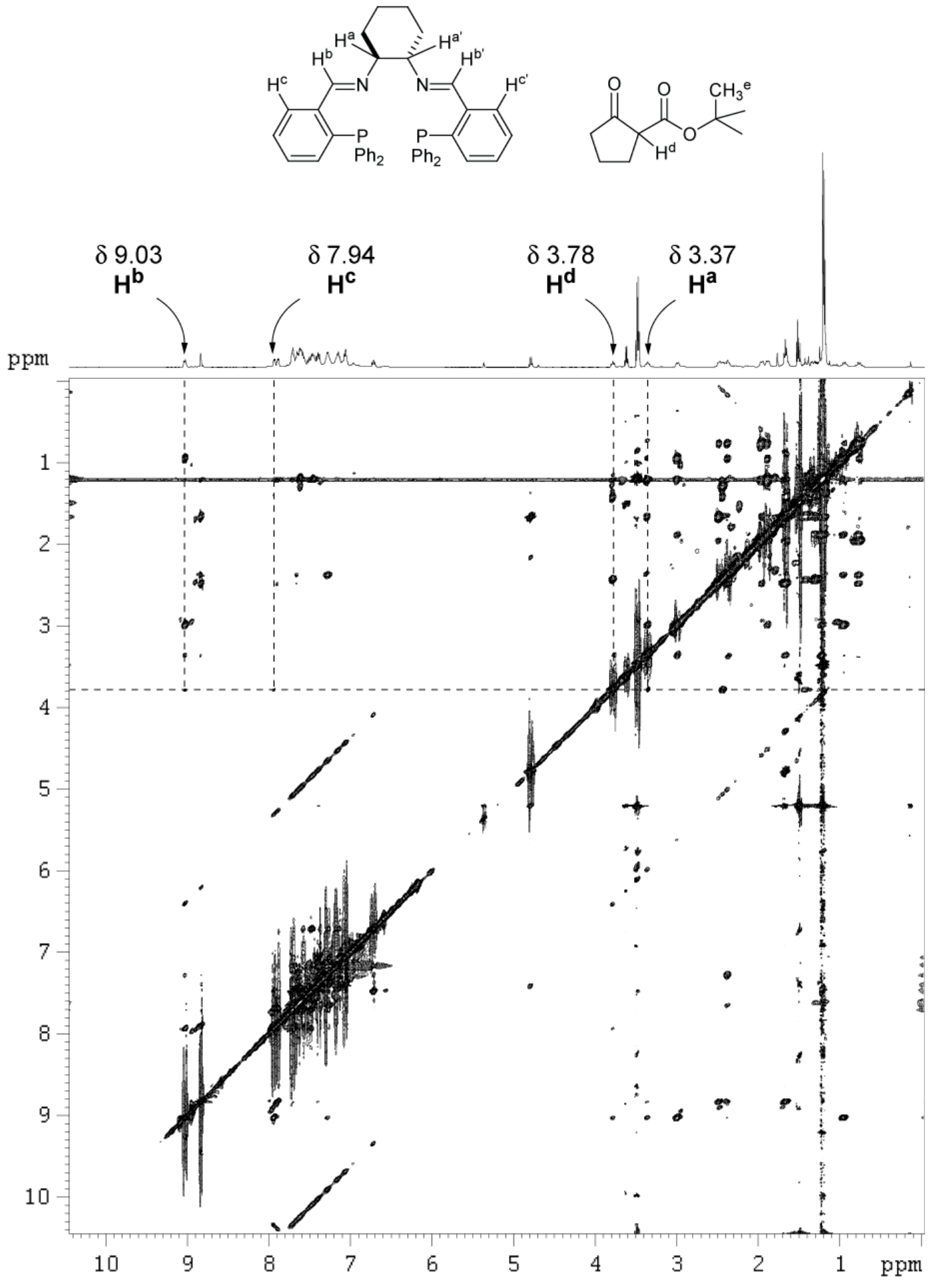
Figure S4. Expansion of the ${ }^{1} \mathrm{H}-{ }^{1} \mathrm{H}$ NOESY NMR spectrum of 4a, showing the NOE contacts of the tert-butyl group in $\beta$-ketoester $2\left(\mathrm{H}^{\mathrm{e}}\right)$ to imine- $\mathrm{H}^{\mathrm{b}}$ and benzylidene- $\mathrm{H}^{\mathrm{c}}$ of the PNNP ligand.
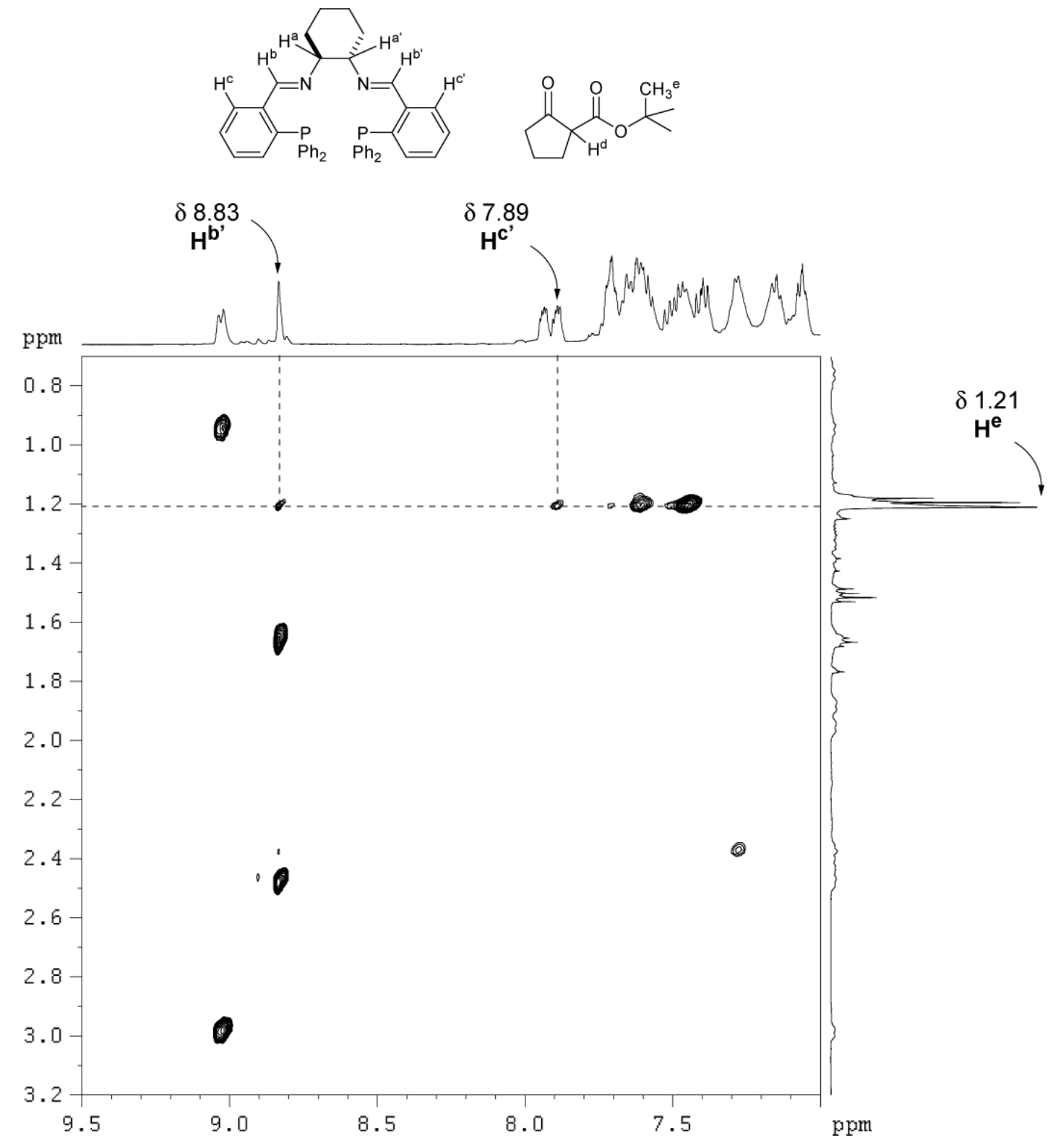
(1S,2S)-2-tert-Butoxycarbonylcyclopentanoato $\left\{N, N^{\prime}\right.$-bis[2-(diphenylphosphino)-

benzylidene]diaminocyclohexane\}ruthenium(II) Hexafluorophosphate (5a). A solution of $\left[\mathrm{RuCl}_{2}(\mathrm{PNNP})\right](80 \mathrm{mg}, 96 \mu \mathrm{mol})$ and $\left(\mathrm{Et}_{3} \mathrm{O}\right) \mathrm{PF}_{6}\left(49 \mathrm{mg}, 197 \mu \mathrm{mol}, 2.05\right.$ equiv) in $\mathrm{CH}_{2} \mathrm{Cl}_{2}(5$ $\mathrm{mL}$ ) was stirred at room temperature for $16 \mathrm{~h}$. Then, 2-tert-butoxycarbonylcyclopentanone (2) (20 mg, $109 \mu \mathrm{mol}, 1.13$ equiv) in dichloromethane $(1 \mathrm{~mL})$ was added, and the resulting solution was stirred for $1 \mathrm{~h}$ at room temperature. After adding triethylamine $(15 \mu \mathrm{l}, 108 \mu \mathrm{mol}$, 1.13 equiv) and stirring for further 45 minutes, the crude reaction mixture was filtered through a short plug of silica gel with dichloromethane as eluent. After evaporation of the solvent, the orange product was triturated with hexane and dried in vacuum. The analytically pure product was obtained as an orange solid. Yield: $67 \mathrm{mg}(61.6 \mu \mathrm{mol}, 64 \%)$.

${ }^{31} \mathbf{P}\left\{{ }^{1} \mathbf{H}\right\}$ NMR $\left(101 \mathrm{MHz}, \mathrm{CD}_{2} \mathrm{Cl}_{2}\right): \delta 63.4\left(d, 1 \mathrm{P}, J_{\mathrm{P}, \mathrm{P}}=31.2 \mathrm{~Hz}\right), 52.5\left(d, 1 \mathrm{P}, J_{\mathrm{P}, \mathrm{P}}=31.2\right.$ $\mathrm{Hz}),-144.3\left(\right.$ sept, $\left.1 \mathrm{P}, J_{\mathrm{P}, \mathrm{F}}=711 \mathrm{~Hz}, P \mathrm{~F}_{6}\right)$.

${ }^{1} \mathrm{H}$ NMR $\left(500 \mathrm{MHz}, \mathrm{CD}_{2} \mathrm{Cl}_{2}\right): \delta 8.89\left(s, 1 \mathrm{H}, H^{b} \mathrm{C}=\mathrm{N}\right), 8.69\left(d, 1 \mathrm{H}, J_{\mathrm{P}, \mathrm{H}}=9.5 \mathrm{~Hz}, H^{b} \mathrm{C}=\mathrm{N}\right)$, $7.79\left(d d, 1 \mathrm{H}, J_{\mathrm{H}, \mathrm{H}}=7.2,4.1 \mathrm{~Hz}\right.$, benzylidene- $\left.\mathrm{H}^{c^{\prime}}\right), 7.66-7.58$ ( $m, 4 \mathrm{H}$, arom.), $7.53-7.48$ (m, $3 \mathrm{H}$, arom.), 7.46 - 7.34 (m, $7 \mathrm{H}$, arom.), $7.21-7.15$ (m, $6 \mathrm{H}$, arom.), $7.03-6.90$ (m, $4 \mathrm{H}$, arom.), 6.89 (ddd, $2 \mathrm{H}, J_{\mathrm{H}, \mathrm{H}}=7.6,7.6,1.8 \mathrm{~Hz}$, arom.), $6.52\left(d d, 1 \mathrm{H}, J_{\mathrm{H}, \mathrm{H}}=8.7,8.7 \mathrm{~Hz}\right.$, arom.), $3.80-3.71\left(m, 1 \mathrm{H}, H^{a} \mathrm{C}-\mathrm{N}\right), 2.58-2.50\left(m, 1 \mathrm{H}, \mathrm{CH} \mathrm{H}^{\prime}\right), 2.43-2.35(m, 1 \mathrm{H}$,

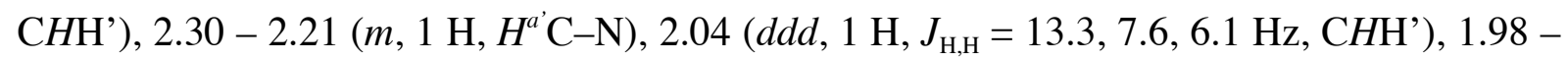
$1.86\left(m, 2 \mathrm{H}, \mathrm{CH}_{2}\right), 1.77-1.66\left(m, 2 \mathrm{H}, \mathrm{CH}_{2}\right), 1.62-1.53\left(m, 1 \mathrm{H}, \mathrm{CH} \mathrm{H}^{\prime}\right), 1.33-1.22(m, 3$ $\left.\mathrm{H}, \mathrm{CH} \mathrm{H}^{\prime}\right), 1.21-1.13\left(m, 3 \mathrm{H}, \mathrm{CH} \mathrm{H}^{\prime}\right), 1.11\left(s, 9 \mathrm{H}, \mathrm{C}\left(\mathrm{CH}_{3}{ }^{e}\right)_{3}\right)$.

${ }^{13} \mathbf{C}\left\{{ }^{1} \mathbf{H}\right\}$ NMR $\left(126 \mathrm{MHz}, \mathrm{CD}_{2} \mathrm{Cl}_{2}\right): \delta 192.0(\mathrm{C}=C-\mathrm{O}), 168.3(\mathrm{COO}), 166.7\left(d, J_{\mathrm{C}, \mathrm{P}}=3.1 \mathrm{~Hz}\right.$, $C=\mathrm{N}), 163.5\left(d, J_{\mathrm{C}, \mathrm{P}}=5.2 \mathrm{~Hz}, C=\mathrm{N}\right), 138.2-126.4(36 \mathrm{C}$, arom. $), 93.1(C=\mathrm{C}-\mathrm{O}), 79.4$ $\left(\mathrm{OC}\left(\mathrm{CH}_{3}\right)_{3}\right), 78.2(C-\mathrm{N}), 68.7(C-\mathrm{N}), 38.9\left(\mathrm{CH}_{2}\right), 32.2\left(\mathrm{CH}_{2}\right), 31.9\left(\mathrm{CH}_{2}\right), 29.3\left(\mathrm{C}\left(\mathrm{CH}_{3}\right)_{3}\right)$, $28.8\left(\mathrm{CH}_{2}\right), 25.0\left(\mathrm{CH}_{2}\right), 24.2\left(\mathrm{CH}_{2}\right), 20.2\left(\mathrm{CH}_{2}\right)$.

Calcd. for $\mathrm{C}_{54} \mathrm{H}_{55} \mathrm{~F}_{6} \mathrm{~N}_{2} \mathrm{O}_{3} \mathrm{P}_{3} \mathrm{Ru}$ (1088.0): C 59.61, H 5.09, N 2.57; found: C 59.86, H 5.20, N 2.54 . 
Figure S5. ${ }^{1} \mathrm{H}-{ }^{1} \mathrm{H}$ NOESY NMR spectrum of 5a. The NOE contacts of the tert-butyl group in the $\beta$-ketoester enolato ligand $\left(\mathrm{H}^{e}\right)$ to imine- $\mathrm{H}^{b^{\prime}}$ and benzylidene- $\mathrm{H}^{c^{\prime}}$ are highlighted.
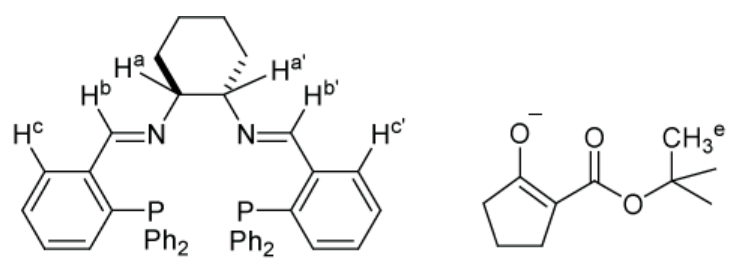

$\delta 1.11$

$\mathrm{H}^{\mathrm{e}}$

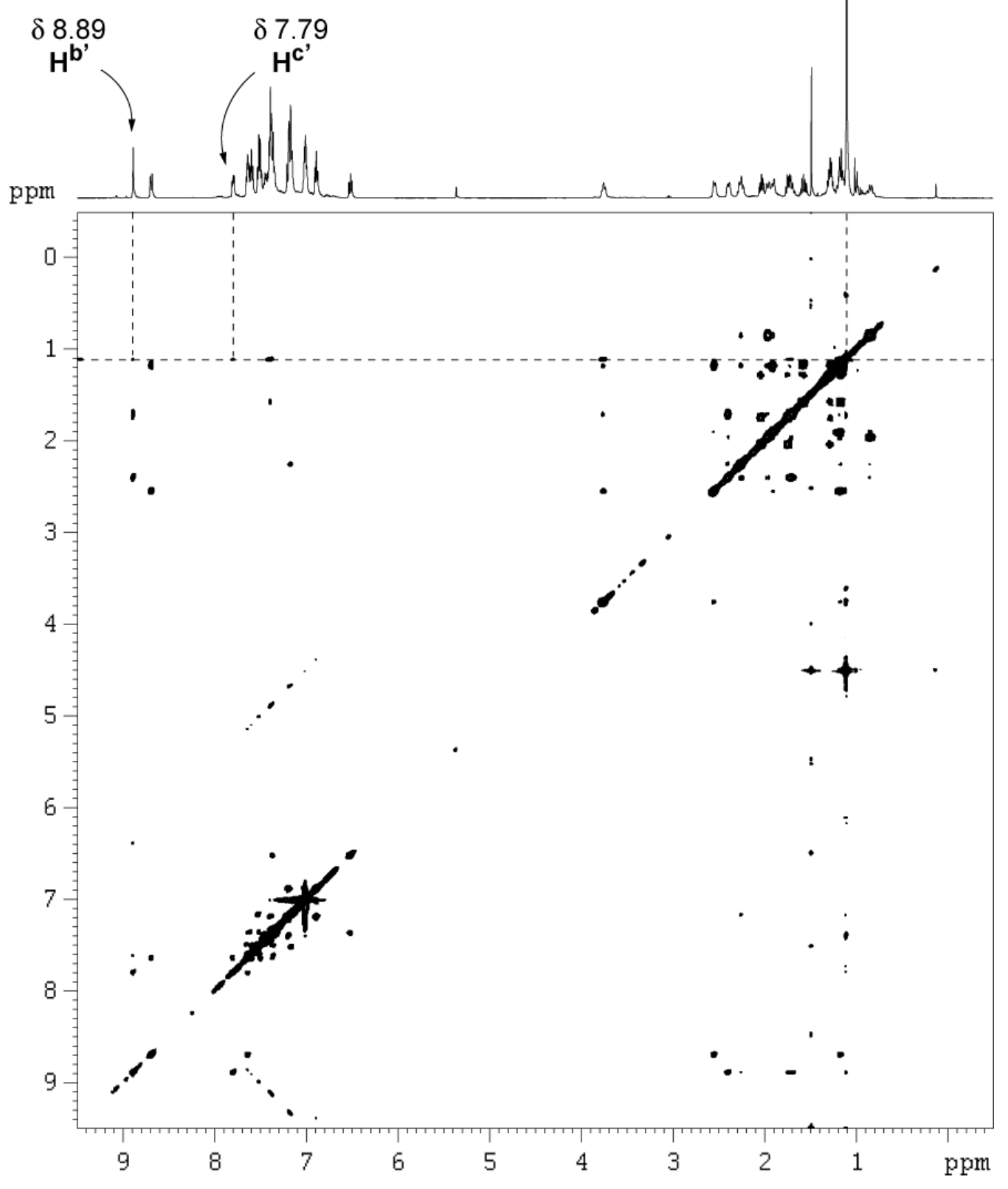

Figure S6. NOE contacts in $\mathbf{4 a}$ (left) and $\mathbf{5 a}$ (right) with ${ }^{1} \mathrm{H}$ chemical shifts (in ppm). 

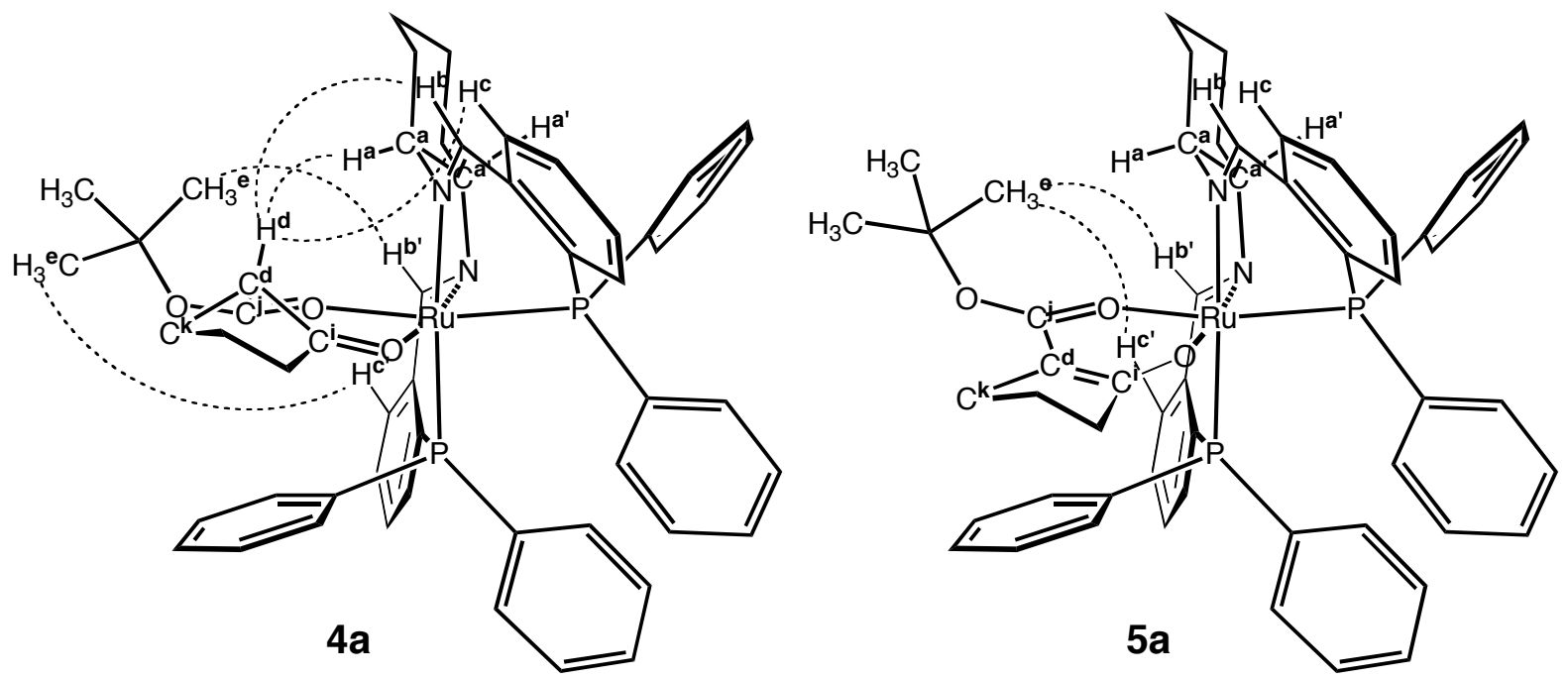

$(1 S, 2 S)-\alpha$-Acetyl- $N$-benzyl- $\delta$-valerolactame $\left\{N, N^{\prime}\right.$-bis[2-(diphenylphosphino)benz-

ylidene]diaminocyclohexane\}ruthenium(II) Bis(hexafluorophosphate) (4b). A solution of $\left(\mathrm{Et}_{3} \mathrm{O}\right) \mathrm{PF}_{6}(120 \mathrm{mg}, 0.48 \mathrm{mmol}, 2.0$ equiv $)$ in $\mathrm{CH}_{2} \mathrm{Cl}_{2}(2 \mathrm{~mL})$ was added to $\left[\mathrm{RuCl}_{2}(\mathrm{PNNP})\right]$ (200 mg, $0.24 \mathrm{mmol})$ in $\mathrm{CH}_{2} \mathrm{Cl}_{2}(3 \mathrm{~mL})$, and the resulting solution was stirred for $6 \mathrm{~h} . \alpha-$ Acetyl- $N$-benzyl- $\delta$-valerolactame $(3)\left(60 \mathrm{mg}, 0.26 \mathrm{mmol}, 1.1\right.$ equiv) in $\mathrm{CH}_{2} \mathrm{Cl}_{2}(2 \mathrm{~mL})$ was added to the reaction solution, which turned from deep-brown to orange. After stirring for 12 $\mathrm{h}$, the solvent was evaporated under reduced pressure, and the yellow solid was washed with hexane. Yield: $280 \mathrm{mg}(91 \%)$.

${ }^{31} \mathbf{P}\left\{{ }^{1} \mathbf{H}\right\}$ NMR $\left(101 \mathrm{MHz}, \mathrm{CD}_{2} \mathrm{Cl}_{2}\right): \delta 60.7\left(d, 1 \mathrm{P}, J_{\mathrm{P}, \mathrm{P}}{ }^{\prime}=28.9 \mathrm{~Hz}\right), 50.5\left(d, 1 \mathrm{P}, J_{\mathrm{P}, \mathrm{P}}=28.9\right.$ $\mathrm{Hz}),-144.3\left(\right.$ sept, $\left.2 \mathrm{P}, J_{\mathrm{P}, \mathrm{F}}=711 \mathrm{~Hz}, P \mathrm{~F}_{6}\right)$.

${ }^{1} \mathrm{H}$ NMR $\left(500 \mathrm{MHz}, \mathrm{CD}_{2} \mathrm{Cl}_{2}\right): \delta 8.90\left(d, 1 \mathrm{H}, J_{\mathrm{P}, \mathrm{H}}=9.5 \mathrm{~Hz}, H^{b} \mathrm{C}=\mathrm{N}\right), 8.36\left(s, 1 \mathrm{H}, H^{b} \mathrm{C}=\mathrm{N}\right)$, $8.05-8.00\left(m, 1 \mathrm{H}\right.$, benzylidene- $\left.\mathrm{H}^{c}\right), 7.95-6.70(m, 29 \mathrm{H}$, arom. $), 6.83\left(d, 2 \mathrm{H}, J_{\mathrm{H}, \mathrm{H}}=7.46\right.$ $\mathrm{Hz}$, ortho-NBn- $\left.H^{h}\right), 6.66-6.57\left(m, 1 \mathrm{H}\right.$, arom.), $4.19\left(d, 1 \mathrm{H}, J_{\mathrm{H}, \mathrm{H}}=15.5 \mathrm{~Hz}, \mathrm{NCH}^{g} \mathrm{H}^{\mathrm{g}} \mathrm{Ph}\right)$, $3.75\left(d, 1 \mathrm{H}, J_{\mathrm{H}, \mathrm{H}}=15.5 \mathrm{~Hz}, \mathrm{NCH}^{\mathrm{g}} H^{g} \mathrm{Ph}\right), 3.63\left(d d, 1 \mathrm{H}, J_{\mathrm{H}, \mathrm{H}}=11.0,5.5 \mathrm{~Hz}, \mathrm{C}(\mathrm{O}) \mathrm{C} H^{f} \mathrm{C}(\mathrm{O}) \mathrm{N}\right)$, 3.45 - $3.40\left(m, 1 \mathrm{H}, \mathrm{NCHH}^{\prime} \mathrm{CH}_{2}\right), 3.35-3.26\left(m, 1 \mathrm{H}, \mathrm{NCH}^{\prime} \mathrm{CH}_{2}\right), 2.79-2.73(m, 1 \mathrm{H}$, CHH'), $2.73-2.65\left(m, 1 \mathrm{H}, H^{a} \mathrm{C}-\mathrm{N}\right), 2.27-2.13\left(m, 1 \mathrm{H}, \mathrm{CH} \mathrm{H}^{\prime}\right), 2.03-1.95\left(m, 2 \mathrm{H}, \mathrm{CH}_{2}\right)$, 
$1.97-1.88\left(m, 1 \mathrm{H}, H^{a} \mathrm{C}-\mathrm{N}\right), 1.89-1.83\left(m, 2 \mathrm{H}, \mathrm{CH}_{2}\right), 1.77-1.68\left(m, 2 \mathrm{H}, \mathrm{CH}_{2}\right), 1.32-$ $1.21\left(m, 2 \mathrm{H}, \mathrm{CH}_{2}\right), 1.59\left(s, 3 \mathrm{H}, \mathrm{CH}_{3}\right), 0.92-0.82\left(m, 1 \mathrm{H}, \mathrm{CH} \mathrm{H}^{\prime}\right), 0.83-0.71(m, 1 \mathrm{H}$, CH').

${ }^{13} \mathbf{C}\left\{{ }^{1} \mathbf{H}\right\}$ NMR $\left(176 \mathrm{MHz}, \mathrm{CD}_{2} \mathrm{Cl}_{2}\right): \delta 218.8\left(\mathrm{CH}_{3} C^{l} \mathrm{O}\right), 169.2\left(d, J_{\mathrm{C}, \mathrm{P}}=5.0 \mathrm{~Hz}, C=\mathrm{N}\right), 167.4$ $\left(d, J_{\mathrm{C}, \mathrm{P}}=5.0 \mathrm{~Hz}, C=\mathrm{N}\right), 167.2\left(C^{m}(\mathrm{O})-\mathrm{N}\right), 139.0-125.4(42 \mathrm{C}$, arom. $), 78.0\left(C^{a^{\prime}}-\mathrm{N}\right), 69.4$ $\left(C^{a}-\mathrm{N}\right), 53.5\left(\mathrm{NCH}_{2} \mathrm{Ph}\right), 50.9\left(\mathrm{NCH}_{2} \mathrm{CH}_{2}\right), 50.5\left(\mathrm{C}(\mathrm{O}) C^{f} \mathrm{HC}(\mathrm{O}) \mathrm{N}\right), 31.4\left(\mathrm{CH}_{2}\right), 31.2\left(\mathrm{CH}_{2}\right)$, 31.2 $\left(\mathrm{CH}_{3}\right), 25.0\left(\mathrm{NCH}_{2} \mathrm{CH}_{2} \mathrm{C}^{n} \mathrm{H}_{2}\right), 24.7\left(\mathrm{CH}_{2}\right), 23.4\left(\mathrm{CH}_{2}\right), 20.6\left(\mathrm{CH}_{2}\right)$.

${ }^{19}$ F NMR $\left(188 \mathrm{MHz}, \mathrm{CD}_{2} \mathrm{Cl}_{2}\right): \delta-72.5\left(d, 12 \mathrm{~F}, J_{\mathrm{F}, \mathrm{P}}=712 \mathrm{~Hz}, \mathrm{PF}_{6}\right)$.

MS (MALDI): $m / z, 990\left(\mathrm{M}^{+}\left(-\mathrm{H}^{+}\right), 61\right), 759\left(\mathrm{M}^{+}-\mathbf{3}, 100\right), 573\left(\mathrm{M}^{+}-\mathbf{3}-2 \mathrm{PPh}_{2}, 10\right)$.

Calcd. for $\mathrm{C}_{58} \mathrm{H}_{57} \mathrm{~F}_{12} \mathrm{~N}_{3} \mathrm{O}_{2} \mathrm{P}_{4} \mathrm{Ru}$ : C, 54.38; H, 4.48; N, 3.28. Found: C, 54.73; H, 4.87; N, 3.07. 
Figure S7. Expansion of the one-bond ${ }^{13} \mathrm{C}-{ }^{1} \mathrm{H}$ HMQC NMR spectrum of $\mathbf{4 b}$, showing $\mathrm{H}^{\mathrm{f}}$ bound to $\mathrm{C}^{\mathrm{f}}$ in $\beta$-ketolactam 3 , and the $\mathrm{H}^{\mathrm{a}}-\mathrm{C}^{\mathrm{a}}$ - and $\mathrm{H}^{\mathrm{a}}-\mathrm{C}^{\mathrm{a}}$-correlation in the PNNP ligand.
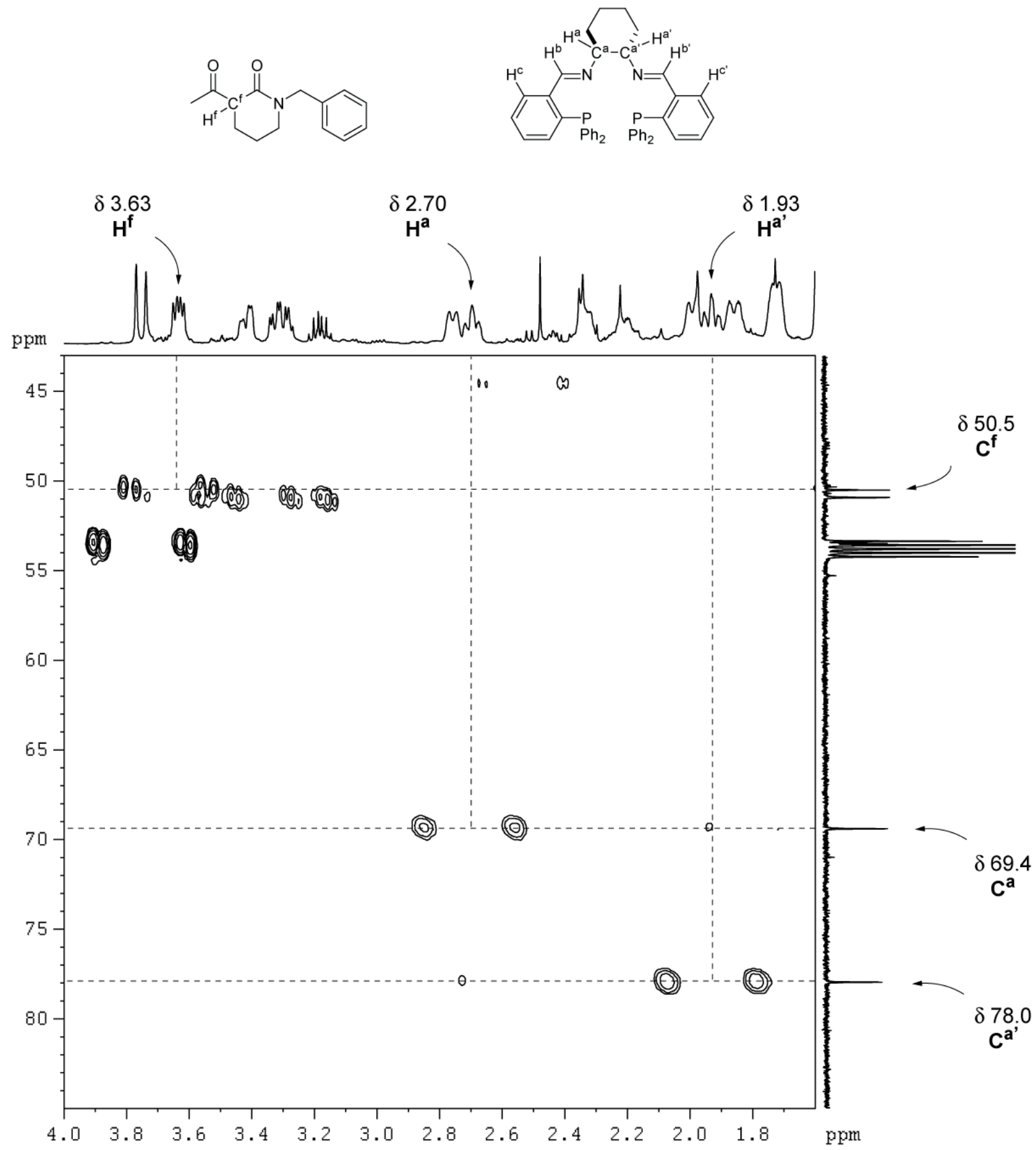
Figure S8. Expansion of the long-range ${ }^{13} \mathrm{C}-{ }^{1} \mathrm{H}$ HMQC NMR spectrum of $\mathbf{4 b}$, with highlighted long-range correlations of the proton $\mathrm{H}^{\mathrm{f}}$ in $\beta$-ketolactam 3 with the three adjacent carbon atoms $\mathrm{C}^{\mathrm{l}}, \mathrm{C}^{\mathrm{m}}$, and $\mathrm{C}^{\mathrm{n}}$.

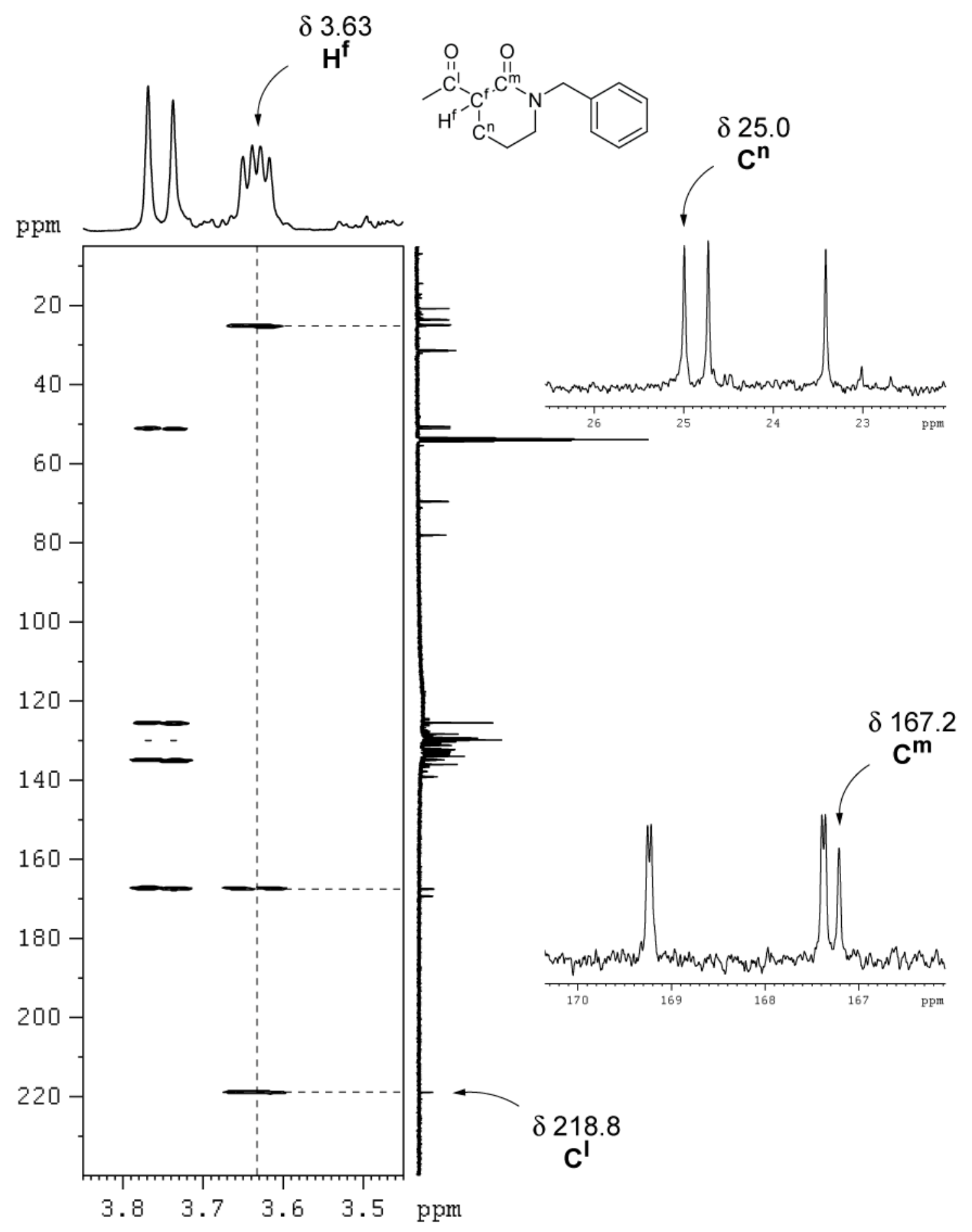


Figure S9. ${ }^{1} \mathrm{H}-{ }^{1} \mathrm{H}$ NOESY NMR spectrum of $\mathbf{4 b}$, with highlighted NOE contacts between the $\alpha$-proton of $\beta$-ketolactame $3\left(\mathrm{H}^{\mathrm{f}}\right)$ and three protons of the PNNP ligand $\left(\mathrm{H}^{\mathrm{a}}, \mathrm{H}^{\mathrm{b}}\right.$, and $\left.\mathrm{H}^{\mathrm{c}}\right)$.
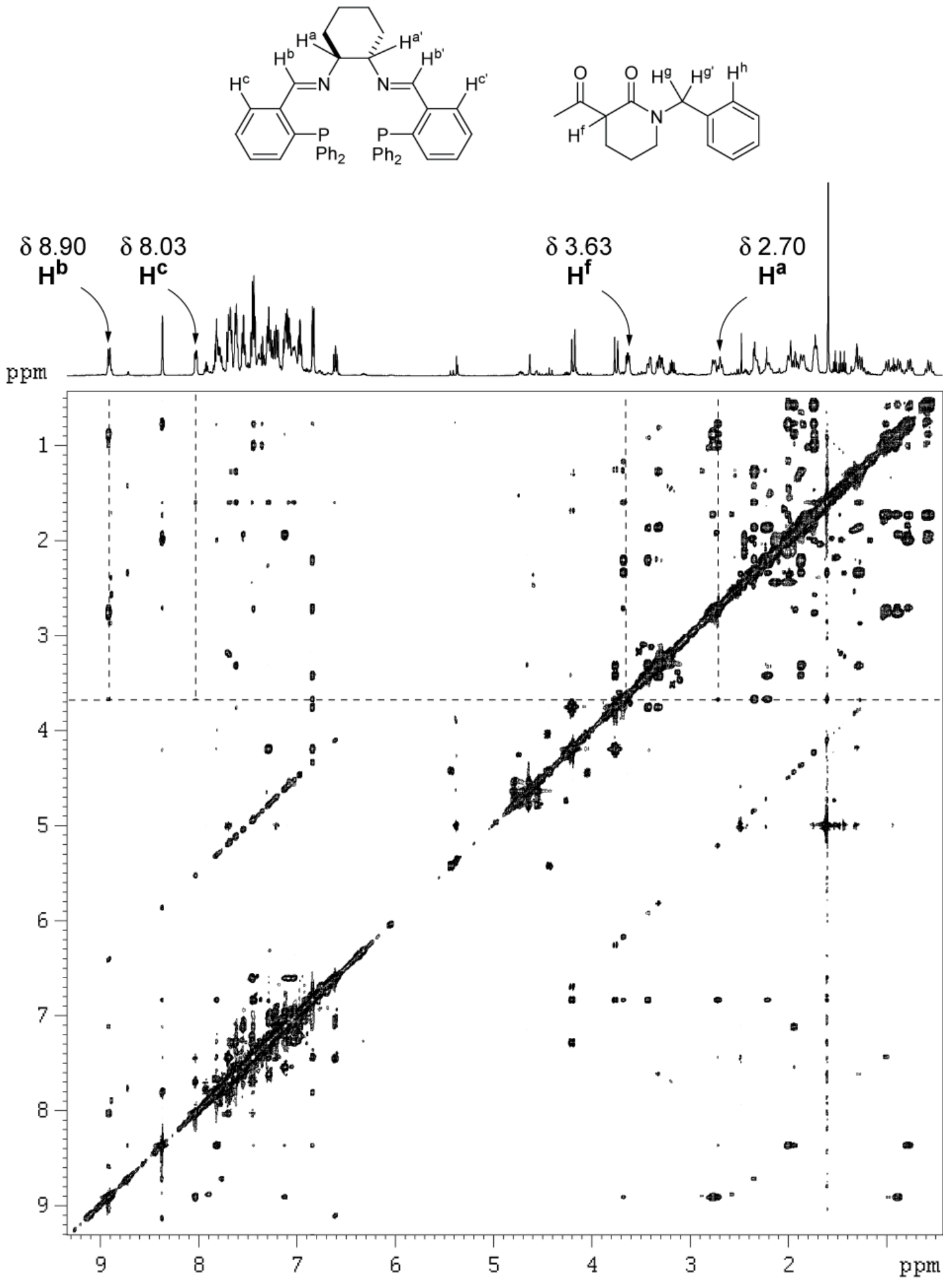
Figure S10. Expansion of the ${ }^{1} \mathrm{H}-{ }^{1} \mathrm{H}$ NOESY NMR spectrum of $\mathbf{4 b}$ showing the NOE contacts of the benzyl group in $\beta$-ketolactam $3\left(\mathrm{H}^{\mathrm{g}}\right.$ and $\left.\mathrm{H}^{\mathrm{h}}\right)$ to the imine proton $\mathrm{H}^{\mathrm{b}}$ and the $\mathrm{H}^{\mathrm{c}^{\prime}}$ of the PNNP benzylidene.
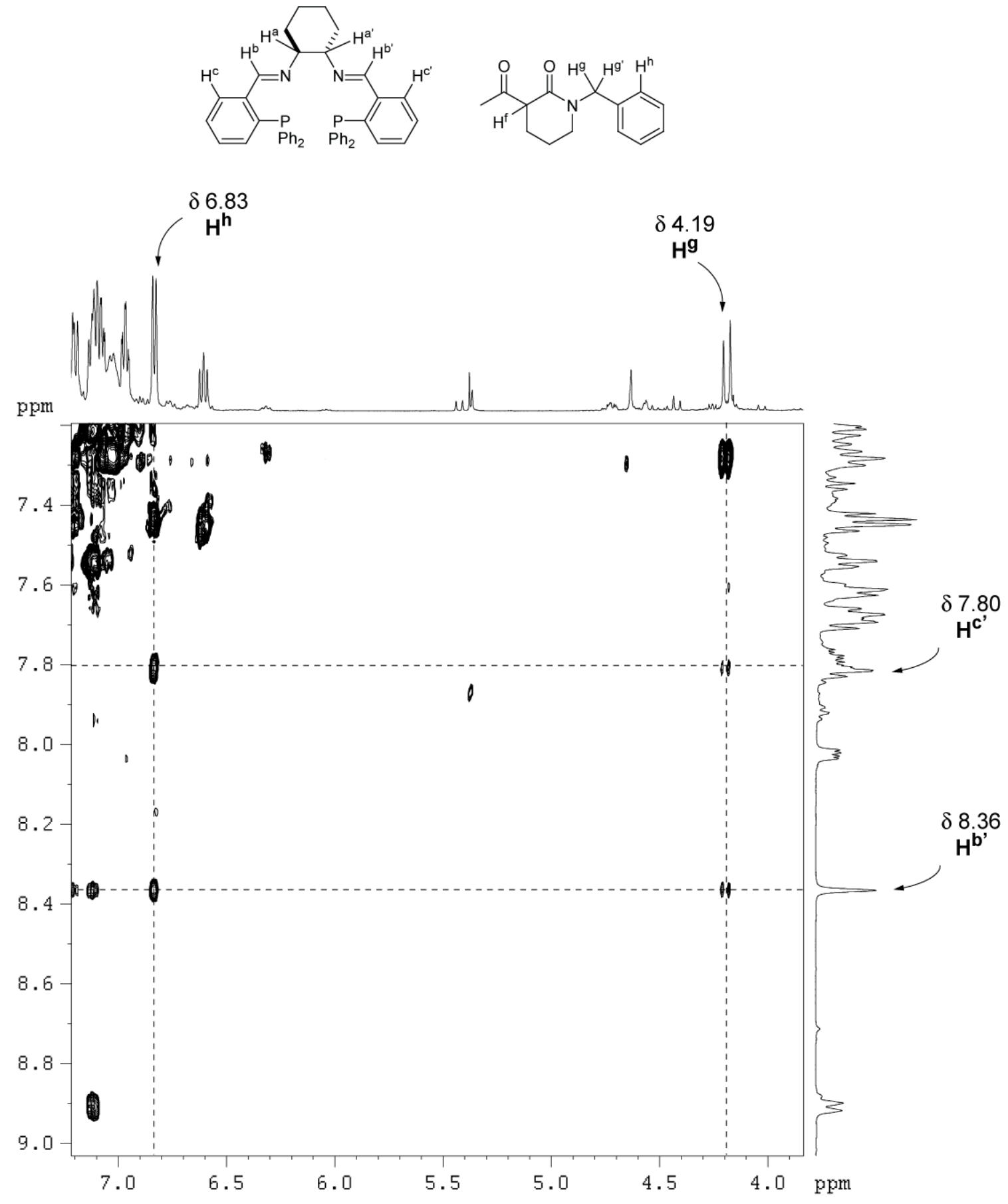

$(1 S, 2 S)-\alpha$-Acetyl- $N$-benzyl- $\delta$-valerolactamato $\left\{N, N^{\prime}\right.$-bis[2-(diphenylphosphino)-

benzylidene]diaminocyclohexane\}ruthenium(II) Hexafluorophosphate (5b). A solution of $\left(\mathrm{Et}_{3} \mathrm{O}\right) \mathrm{PF}_{6}\left(64 \mathrm{mg}, 0.255 \mathrm{mmol}, 2.0\right.$ equiv) in $\mathrm{CH}_{2} \mathrm{Cl}_{2}(2 \mathrm{~mL})$ was added to $\left[\mathrm{RuCl}_{2}(\mathrm{PNNP})\right]$ 
(106 mg, $0.127 \mathrm{mmol})$ in $\mathrm{CH}_{2} \mathrm{Cl}_{2}(3 \mathrm{~mL})$, and the resulting solution was stirred for $6 \mathrm{~h} . \alpha$ Acetyl- $N$-benzyl- $\delta$-valerolactame (3) $\left(29 \mathrm{mg}, 0.127 \mathrm{mmol}, 1.0\right.$ equiv) in $\mathrm{CH}_{2} \mathrm{Cl}_{2}(2 \mathrm{ml})$ was added to the solution, whose color turned from deep brown to orange. After stirring the solution for $2 \mathrm{~h}$, triethylamine was added $(0.018 \mathrm{ml}, 0.129 \mathrm{mmol}, 1.02$ equiv). The solution turned instantaneously to red. The solvent was evaporated after $1 \mathrm{~h}$ under reduced pressure, and the red solid was washed with hexane. A flash chromatography on silica gel $\left(\mathrm{CH}_{2} \mathrm{Cl}_{2}\right)$ afforded the product as a red crystalline solid. Yield: $80 \mathrm{mg}(55 \%)$.

${ }^{31} \mathbf{P}\left\{{ }^{1} \mathbf{H}\right\}$ NMR $\left(121 \mathrm{MHz}, \mathrm{CD}_{2} \mathrm{Cl}_{2}\right): \delta 61.5\left(d, 1 \mathrm{P}, J_{\mathrm{P}, \mathrm{P}}=30.4 \mathrm{~Hz}\right), 51.9\left(d, 1 \mathrm{P}, J_{\mathrm{P}, \mathrm{P}}=30.4\right.$ $\mathrm{Hz}),-144.3\left(\right.$ sept $\left., 1 \mathrm{P}, J_{\mathrm{P}, \mathrm{F}}=711 \mathrm{~Hz}, P \mathrm{~F}_{6}\right)$.

${ }^{1} \mathbf{H}$ NMR $\left(300 \mathrm{MHz}, \mathrm{CD}_{2} \mathrm{Cl}_{2}\right): \delta 8.56\left(s, 1 \mathrm{H}, H^{b} \mathrm{C}=\mathrm{N}\right), 8.54\left(d, 1 \mathrm{H}, J_{\mathrm{P}, \mathrm{H}}=11.7 \mathrm{~Hz}, H^{b} \mathrm{C}=\mathrm{N}\right)$, $7.75-7.67\left(m, 1 \mathrm{H}\right.$, benzylidene- $\left.H^{c^{\prime}}\right), 7.67-6.83(m, 30 \mathrm{H}$, arom. $), 6.90\left(d, 1 \mathrm{H}, J_{\mathrm{H}, \mathrm{H}}=8.1\right.$ $\mathrm{Hz}$, ortho-NBn- $\left.H^{h}\right), 6.51\left(\mathrm{dd}, 1 \mathrm{H}, J_{\mathrm{H}, \mathrm{H}^{\prime}}=8.6,8.6 \mathrm{~Hz}\right.$, arom. $), 4.38\left(d, 1 \mathrm{H}, J_{\mathrm{H}, \mathrm{H}}=16.1 \mathrm{~Hz}\right.$, $\left.\mathrm{NCH}^{g} \mathrm{H}^{\mathrm{g}} \mathrm{Ph}\right), 3.44\left(d, 1 \mathrm{H}, J_{\mathrm{H}, \mathrm{H}}=16.1 \mathrm{~Hz}, \mathrm{NCH}^{\mathrm{g}} H^{g^{\prime}} \mathrm{Ph}\right), 3.20-3.05\left(m, 1 \mathrm{H}, H^{a} \mathrm{C}-\mathrm{N}\right), 3.15-$ $3.06\left(m, 1 \mathrm{H}, \mathrm{NCH} \mathrm{H}^{\prime} \mathrm{CH}_{2}\right), 3.00-2.90\left(m, 1 \mathrm{H}, \mathrm{NCH} H^{\prime} \mathrm{CH}_{2}\right), 2.30-2.20\left(m, 1 \mathrm{H}, \mathrm{CHH}^{\prime}\right)$, $2.1-1.9\left(m, 2 \mathrm{H}, \mathrm{CH}_{2}\right), 2.00-1.88\left(m, 1 \mathrm{H}, H^{a^{\prime}} \mathrm{C}-\mathrm{N}\right), 1.83-1.71\left(m, 1 \mathrm{H}, \mathrm{C} H \mathrm{H}^{\prime}\right), 1.70-$ $1.52\left(m, 4 \mathrm{H}, \mathrm{CH}_{2}\right), 1.15\left(s, 3 \mathrm{H}, \mathrm{CH}_{3}\right), 1.08-0.93\left(m, 1 \mathrm{H}, \mathrm{CH}_{2}\right), 0.96-0.82\left(m, 1 \mathrm{H}, \mathrm{CH}_{2}\right)$, $0.77-0.59\left(m, 2 \mathrm{H}, \mathrm{CH}_{2}\right)$.

${ }^{13} \mathbf{C}\left\{{ }^{1} \mathbf{H}\right\}$ NMR $\left(176 \mathrm{MHz}, \mathrm{CD}_{2} \mathrm{Cl}_{2}\right): \delta 178.3\left(\mathrm{CH}_{3} C(\mathrm{O})=\mathrm{C}\right), 164.9(C=\mathrm{N}), 163.1(C \mathrm{O}-\mathrm{N})$, $161.6\left(d, J_{\mathrm{C}, \mathrm{P}}=5.3 \mathrm{~Hz}, C=\mathrm{N}\right), 139.1-124.8(42 \mathrm{C}$, arom. $), 89.0\left(\mathrm{CH}_{3} \mathrm{C}(\mathrm{O})=C\right), 77.9(C-\mathrm{N})$, $68.1(C-\mathrm{N}), 51.2\left(\mathrm{NCH}_{2} \mathrm{Ph}\right), 49.1\left(\mathrm{NCH}_{2} \mathrm{CH}_{2}\right), 31.1\left(\mathrm{CH}_{2}\right), 30.9\left(\mathrm{CH}_{2}\right), 26.5\left(\mathrm{CH}_{2}\right), 25.6$ $\left(\mathrm{CH}_{3}\right), 24.4\left(\mathrm{CH}_{2}\right), 23.0\left(\mathrm{CH}_{2}\right), 22.7\left(\mathrm{CH}_{2}\right)$.

${ }^{19}$ F NMR $\left(188 \mathrm{MHz}, \mathrm{CD}_{2} \mathrm{Cl}_{2}\right): \delta-73.4\left(d, 12 \mathrm{~F}, J_{\mathrm{F}, \mathrm{P}}=712 \mathrm{~Hz}, \mathrm{P} F_{6}\right)$.

MS (ESI): $m / z 990\left(\mathbf{M}^{+}, 100\right), 759\left(\mathbf{M}^{+}\right.$- enolato, 5), $573\left(\mathbf{M}^{+}\right.$- enolato - $\left.2 \mathrm{PPh}_{2}, 10\right)$. 
Figure S11. ${ }^{1} \mathrm{H}^{-1} \mathrm{H}$ NOESY NMR spectrum of $\mathbf{5 b}$, with highlighted NOE contacts of the benzyl group of $\beta$-ketolactamato $3\left(\mathrm{H}^{\mathrm{g}}\right.$ and $\left.\mathrm{H}^{\mathrm{h}}\right)$ to the imine- $\mathrm{H}^{\mathrm{b}}$ and benzylidene- $\mathrm{H}^{\mathrm{c}^{\prime}}$ of the PNNP ligand.
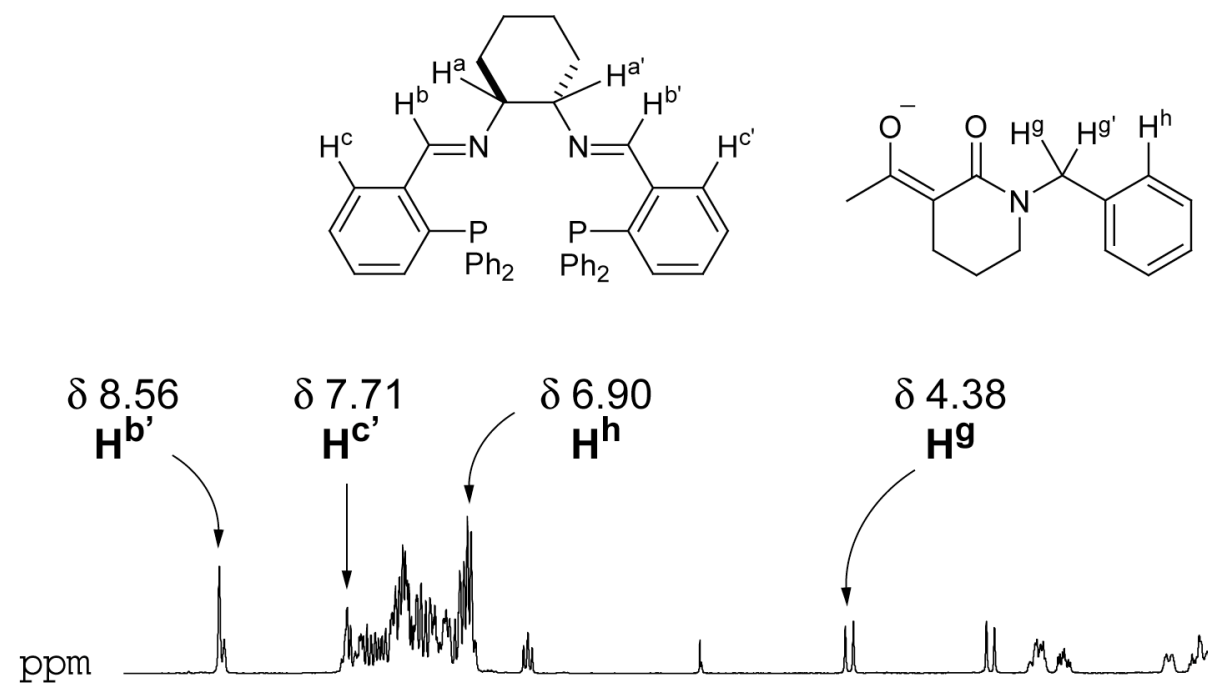

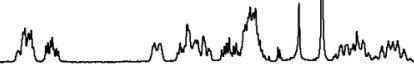

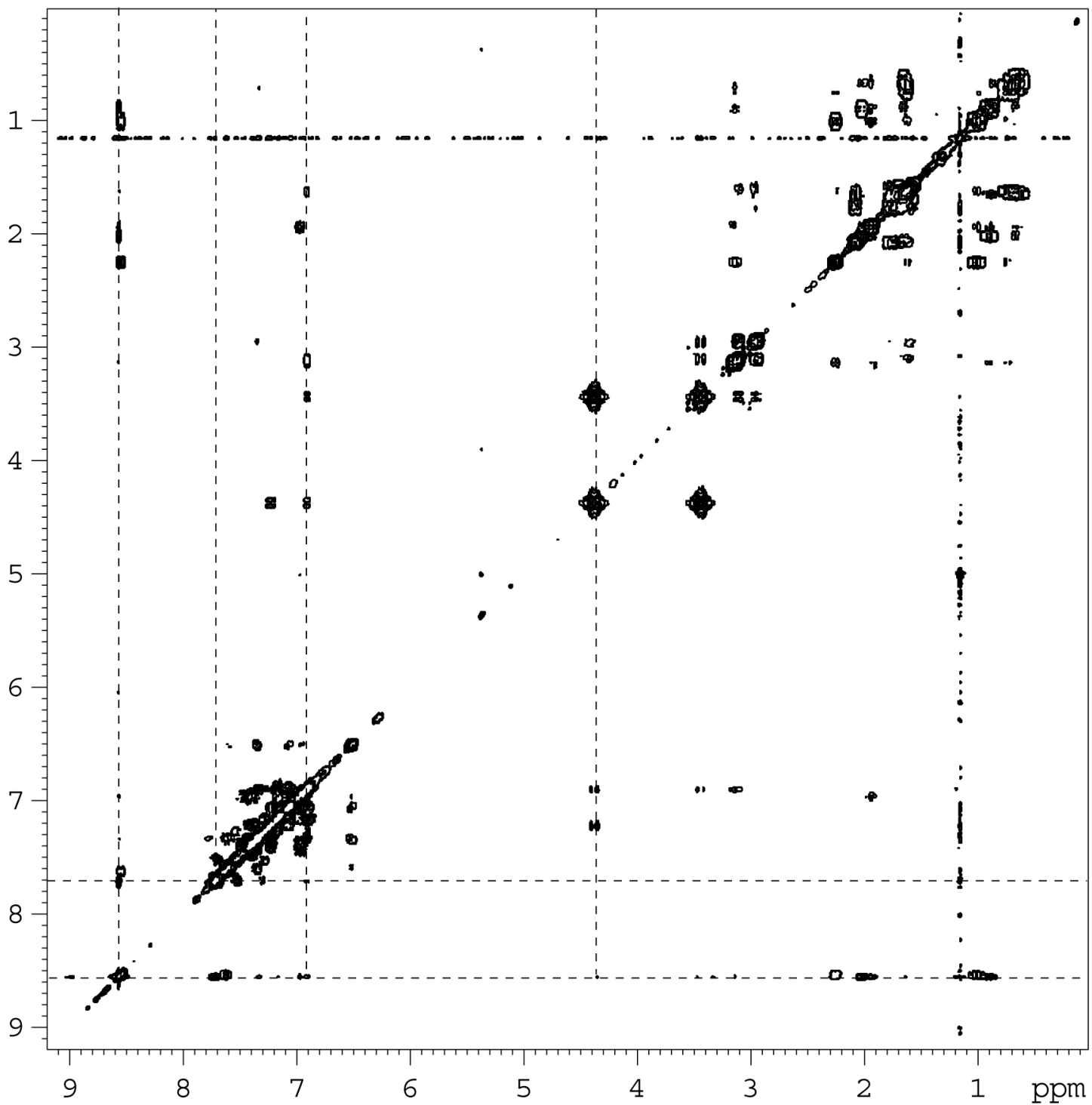


Figure S12. NOE contacts in $\mathbf{4 b}$ (left) and $\mathbf{5 b}$ (right) with ${ }^{1} \mathrm{H}$ chemical shifts (in ppm).
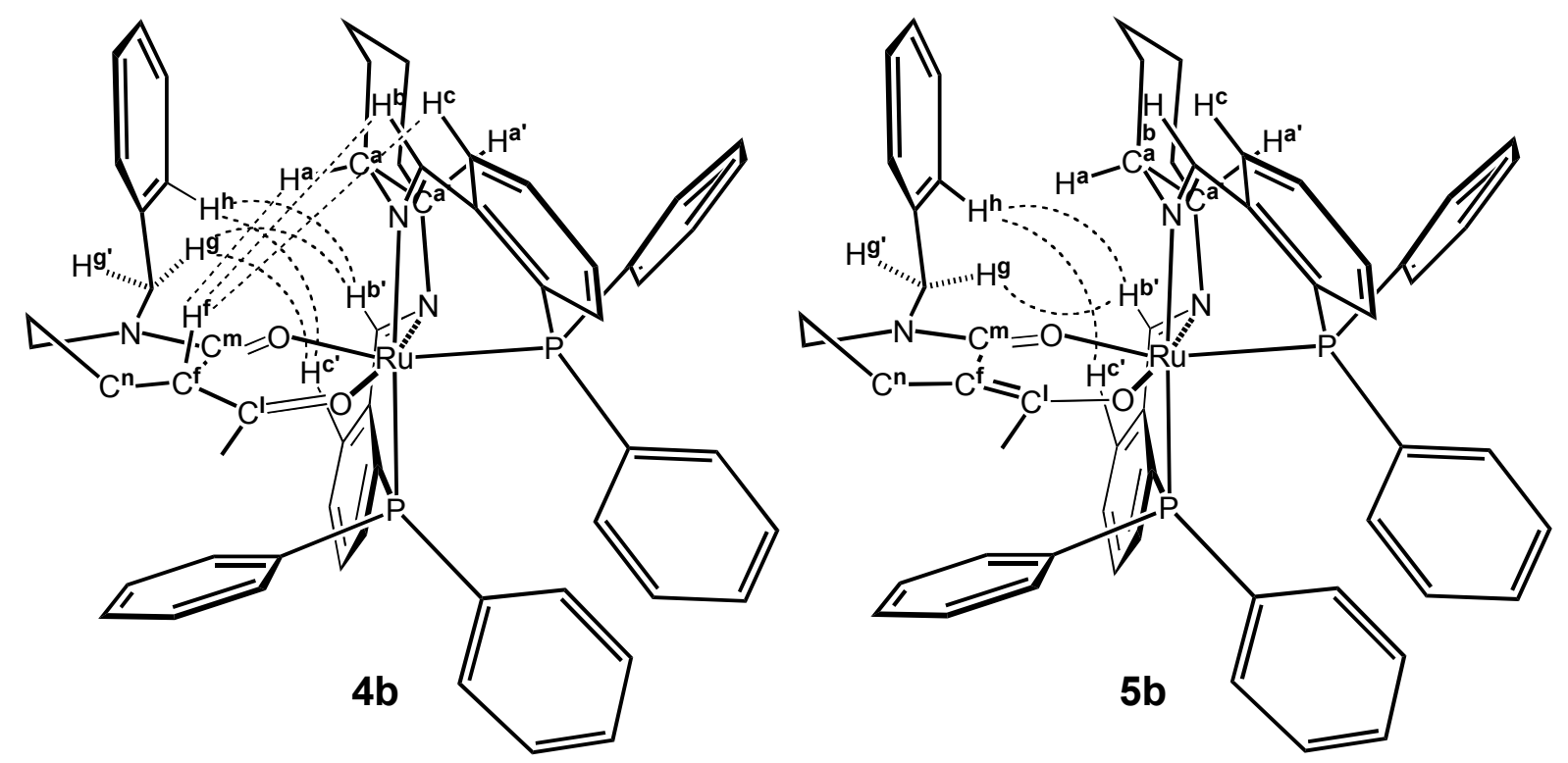

$\mathbf{p} K_{a}^{a q}$ Measurements and Reference Data. To eliminate the effect of the solvent, all $\mathrm{p} K_{a}$ values are on the pseudo-aqueous scale $\left(\mathrm{p} K_{a}^{a q}\right){ }^{2}$ The following $\mathrm{p} K_{a}^{a q}$ are literature values: $\mathrm{HPPh}_{3}{ }^{+}, 2.7 ;^{3 \mathrm{a}} \mathrm{HNEt}_{3}{ }^{+}, 10.8 ;^{4} \mathrm{HOEt}_{2}{ }^{+},-3.6 .{ }^{5}$ Very recently, Pestovsky and Bakac reported a $\mathrm{p} K_{a}$ value for $\mathrm{HPPh}_{3}{ }^{+}$of $1.05 \pm 0.06$ based on ${ }^{31} \mathrm{P} \mathrm{NMR}$ and kinetic measurements in $\mathrm{CH}_{3} \mathrm{CN} / \mathrm{H}_{2} \mathrm{O}$ mixtures. ${ }^{3 \mathrm{~b}}$ From their data, they estimate the pseudo-aqueous $\mathrm{p} K_{a}^{a q}$ to be about 0 . The $\mathrm{p} K_{a}^{a q}$ value of 2-tert-butoxycarbonylcyclopentanone (2) can be estimated to be 10.5, as reported for 2-ethoxycarbonylcyclopentanone. ${ }^{6}$ The $\mathrm{p}_{a}^{a q}$ of $\mathbf{8}$, the enolate intermediate which would be formed by the first step of the 1,4-addition reaction between $\mathbf{6}$ and $\mathbf{5 a}$, is expected to be $\sim 20$ on the basis of the aqueous $\mathrm{p} K_{a}^{a q}$ of 19 reported for acetone. ${ }^{7}$<smiles>[3H]CCC1(C(=O)OC(C)(C)C)CCCC1=O</smiles>

The $\mathrm{p} K_{a}^{a q}$ of protonated methyl vinyl ketone is estimated to be approximately -4 , as a $\mathrm{p} K_{a}^{a q}$ value of -2.87 (on the aqueous scale) has been attributed to protonated 3-methyl-3- 
penten-2-one, ${ }^{8 a}$ and methyl vinyl ketone has been found to be less basic than 3-methyl-3penten-2-one on the $\mathrm{H}_{\mathrm{B}}$ scale by about $1.2 \mathrm{pK}$ units. ${ }^{8 \mathrm{~b}}$

Triphenylphosphonium Tetrafluoroborate. To a $\mathrm{CH}_{2} \mathrm{Cl}_{2}$ solution (3 $\left.\mathrm{mL}\right)$ of triphenylphosphine $(600 \mathrm{mg}, 2.29 \mathrm{mmol})$, cooled to $0{ }^{\circ} \mathrm{C}$, was added a solution of $\mathrm{HBF}_{4}$ in diethylether ( $54 \mathrm{w}-\%, 0.47 \mathrm{~mL}, 3.41 \mathrm{mmol}, 1.5$ equiv). After $5 \mathrm{~min}$, the mixture was allowed to reach room temperature. Addition of hexane $(1 \mathrm{~mL})$ gave a white precipitate, which was collected by filtration, washed twice with hexane, and dried in vacuum. Yield: $375 \mathrm{mg}(47 \%)$. ${ }^{1} \mathbf{H}$ NMR $\left(250 \mathrm{MHz}, \mathrm{CD}_{2} \mathrm{Cl}_{2}\right) \delta 9.04\left(d, 1 \mathrm{H}, J_{\mathrm{P}, \mathrm{H}}=529 \mathrm{~Hz}, \mathrm{HP}\right), 7.94-7.71$ (m, $15 \mathrm{H}$, arom.). ${ }^{31} \mathbf{P}\left\{{ }^{1} \mathbf{H}\right\} \mathbf{N M R}\left(101.3 \mathrm{MHz}, \mathrm{CD}_{2} \mathrm{Cl}_{2}\right) \delta 4.48(s, 1 \mathrm{P})$.

Estimation of the $\mathbf{p} K_{a}^{a q}$ of $4 \mathbf{a}$. The equilibrium constant $K_{e q}$ of eq 1 is defined in eq 2 :

$$
\begin{gathered}
\mathbf{4 a}+\mathrm{PPh}_{3} \Delta \mathbf{5 a}+\mathrm{HPPh}_{3}^{+} \\
K_{e q}=\frac{[\mathbf{5 a}]\left[\mathrm{HPPh}_{3}^{+}\right]}{[\mathbf{4 a}]\left[\mathrm{PPh}_{3}\right]}
\end{gathered}
$$

The $\mathrm{p} K_{a}$ of $\mathbf{4 a}$ is then calculated according to eq 3 :

$$
p K_{a}(\mathbf{4 a})=p K_{e q}+p K_{a}^{a q}\left(\mathrm{PPh}_{3}\right)
$$

The integrated intensities of the signals of $\mathbf{4 a}, \mathbf{5 a}, \mathrm{PPh}_{3}$, and $\mathrm{HPPh}_{3}{ }^{+}$, obtained from ${ }^{31} \mathrm{P}\left\{\right.$ inverse-gated $\left.{ }^{1} \mathrm{H}\right\}{ }^{9} \mathrm{NMR}$ spectra, can be used directly in eq 2 to calculate $K_{e q}$. In the case of a fast exchange between $\mathrm{PPh}_{3}$ and $\mathrm{HPPh}_{3}{ }^{+}$, a coalescence signal at the chemical shift $\delta_{\text {eq }}$ is observed in the NMR spectrum, and the $\left[\mathrm{HPPh}_{3}{ }^{+}\right] /\left[\mathrm{PPh}_{3}\right]$ ratio can be calculated by the weighted average of chemical shifts by using eq 4 : 


$$
\frac{\left[\mathrm{HPPh}_{3}^{+}\right]}{\left[\mathrm{PPh}_{3}\right]}=\frac{\delta_{e q}-\delta_{\mathrm{PPh}_{3}}}{\delta_{\mathrm{HPPh}_{3}^{+}}-\delta_{e q}}
$$

Furthermore, under the assumption that $[\mathbf{5 a}]=\left[\mathrm{HPPh}_{3}{ }^{+}\right]$and $[\mathbf{4 a}]=\left[\mathrm{PPh}_{3}\right]$, the following approximations for $K_{e q}$ can be made (eqs 5 and 6):

$$
\begin{aligned}
& K_{e q} \cong\left(\frac{[\mathbf{5 a}]}{[\mathbf{4 a}]}\right)^{2} \\
& K_{e q} \cong\left(\frac{\left[\mathrm{PPh}_{3}^{+}\right]}{\left[\mathrm{PPh}_{3}\right]}\right)^{2}
\end{aligned}
$$

Numeric values for the integrated intensities and for the chemical shifts were obtained by using both the Fourier transformed spectrum and a Lorentzian fit.

Deprotonation of 4 a with $\mathbf{P P h}_{3}$. $\left[\mathrm{RuCl}_{2}(\mathrm{PNNP})\right](18 \mathrm{mg}, 21.7 \mu \mathrm{mol})$ and $\left(\mathrm{Et}_{3} \mathrm{O}\right) \mathrm{PF}_{6}$ (10.9 mg, $44 \mu \mathrm{mol}, 2.03$ equiv) were dissolved in dry $\mathrm{CD}_{2} \mathrm{Cl}_{2}(0.6 \mathrm{~mL})$, and the resulting solution was stirred at room temperature for $8 \mathrm{~h}$. After adding 2-tert-butoxycarbonylcyclopentanone (2) $\left(50 \mu \mathrm{L}\right.$ of a solution of $40 \mu \mathrm{L} 2$ in $0.5 \mathrm{~mL} \mathrm{CD}_{2} \mathrm{Cl}_{2}, 22 \mu \mathrm{mol}, 1.02$ equiv), the solution was stirred for additional $16 \mathrm{~h}$. Triphenylphosphine was added (50 $\mu \mathrm{L}$ of a solution of $56.8 \mathrm{mg} \mathrm{PPh}_{3}$ in $0.5 \mathrm{~mL} \mathrm{CD} \mathrm{Cl}_{2}, 21.7 \mu \mathrm{mol}, 1.0$ equiv), and the reaction mixture was analyzed by ${ }^{31} \mathrm{P}\left\{\right.$ inverse-gated $\left.{ }^{1} \mathrm{H}\right\}$ NMR spectroscopy. Fourier spectrum: $[\mathbf{5 a}] /[\mathbf{4 a}]=0.186$, $\delta_{\text {eq }}=-5.05$ (determined with a line broadening factor $l b=15 \mathrm{~Hz}$ ) (Figure 13). Lorentzian fit: $[\mathbf{5 a}] /[\mathbf{4 a}]=0.232, \delta_{\text {eq }}=-4.702$. The chemical shifts $\delta\left(\mathrm{PPh}_{3}\right)=-5.482$ and $\delta\left(\mathrm{HPPh}_{3}{ }^{+}\right)=4.847$ were determined by independent measurements using similar concentrations in $\mathrm{CD}_{2} \mathrm{Cl}_{2}$ as in the deprotonation experiment. The values summarized in Table 1 gave a pseudo-aqueous $\mathrm{p} K_{a}$ $=4.6 \pm 0.5$ for $4 \mathbf{a}$, using a $\mathrm{p} K_{a}^{a q}$ of 2.73 for $\mathrm{HPPh}_{3}{ }^{+},{ }^{3 \mathrm{a}}$ or $\mathrm{p} K_{a}=1.9 \pm 0.5$, using the recently suggested $\mathrm{pK}_{a}^{a q}$ of 0 for $\mathrm{HPPh}_{3}{ }^{+3 \mathrm{~b}}$ 
Table 1. Calculated $\mathrm{p} K_{a}$ values for $\mathbf{4 a}$ on the pseudo-aqueous scale, using eqs $2-4$ and the approximations from eqs 5 and 6.

\begin{tabular}{|c|c|c|c|c|}
\hline \multirow{2}{*}{} & \multicolumn{2}{|c|}{$[\mathbf{5 a}] /[\mathbf{4 a}]$} & \\
\cline { 3 - 5 } & $\begin{array}{c}\text { Fourier: } \\
0.186\end{array}$ & $\begin{array}{c}\text { Lorentzian: } \\
0.232\end{array}$ & $\begin{array}{c}\text { Approx. } \\
\text { eq 6 }\end{array}$ \\
\hline \multirow{3}{*}{$\delta_{\mathrm{eq}}$} & $\begin{array}{c}\text { Fourier: } \\
-5.00\end{array}$ & 4.82 & 4.73 & 5.45 \\
\cline { 2 - 5 } & $\begin{array}{c}\text { Lorentzian: } \\
-4.702\end{array}$ & 4.55 & 4.45 & 4.91 \\
\hline \multirow{3}{*}{} & $\begin{array}{c}\text { Approx: } \\
\text { eq 5 }\end{array}$ & 4.19 & 4.00 & \\
\hline
\end{tabular}

Protonation of $5 \mathbf{a}$ with $\left(\mathbf{H P P h}_{\mathbf{3}}\right) \mathbf{B F}_{\mathbf{4}}$. 5a $(37.3 \mathrm{mg}, 34.3 \mu \mathrm{mol})$ and $\left(\mathrm{HPPh}_{3}\right) \mathrm{BF}_{4}(12.0$ $\mathrm{mg}, 34.3 \mu \mathrm{mol}, 1.0$ equiv) were dissolved in $\mathrm{CD}_{2} \mathrm{Cl}_{2}(0.6 \mathrm{~mL})$, and the reaction mixture was analyzed by ${ }^{31} \mathrm{P}\left\{\right.$ inverse-gated $\left.{ }^{1} \mathrm{H}\right\}$ NMR spectroscopy. The equilibrium signal between $\mathrm{PPh}_{3}$ and $\mathrm{HPPh}_{3}{ }^{+}$did not reach complete coalescence and exhibited a broad shoulder, which was used for the integration in the Fourier spectrum, as well as the average chemical shift $\delta_{\text {eq. }}$. Fourier spectrum: $[\mathbf{5 a}] /[\mathbf{4 a}]=0.155,\left[\mathrm{HPPh}_{3}{ }^{+}\right] /\left[\mathrm{PPh}_{3}\right]=0.168, \delta_{\text {eq }}=-5.10$. Lorentzian fit: $[\mathbf{5 a}] /[\mathbf{4 a}]=0.175, \delta_{\text {eq }}=-5.10 . \delta\left(\mathrm{PPh}_{3}\right)=-5.466$ and $\delta\left(\mathrm{HPPh}_{3}{ }^{+}\right)=4.477$ were determined by independent measurements using similar concentrations in $\mathrm{CD}_{2} \mathrm{Cl}_{2}$ as in the protonation experiment. From the values in Table 2 , the $\mathrm{p} K_{a}$ of $\mathbf{4 a}$ on the pseudo-aqueous scale was calculated as $4.6 \pm 0.5$, using a $K_{a}^{a q}$ of 2.73 for $\mathrm{HPPh}_{3}{ }^{+3 \mathrm{a}}$ or $\mathrm{p} K_{a}=1.9 \pm 0.5$, using the recently suggested $\mathrm{p} K_{a}^{a q}$ of 0 for $\mathrm{HPPh}_{3}{ }^{+3 b}$ 
Figure S13. Example of a ${ }^{31} \mathrm{P}\left\{\right.$ inverse-gated $\left.{ }^{1} \mathrm{H}\right\}$ NMR spectrum from the partial deprotonation of $\mathbf{4 a}$ by $\mathrm{PPh}_{3}$.

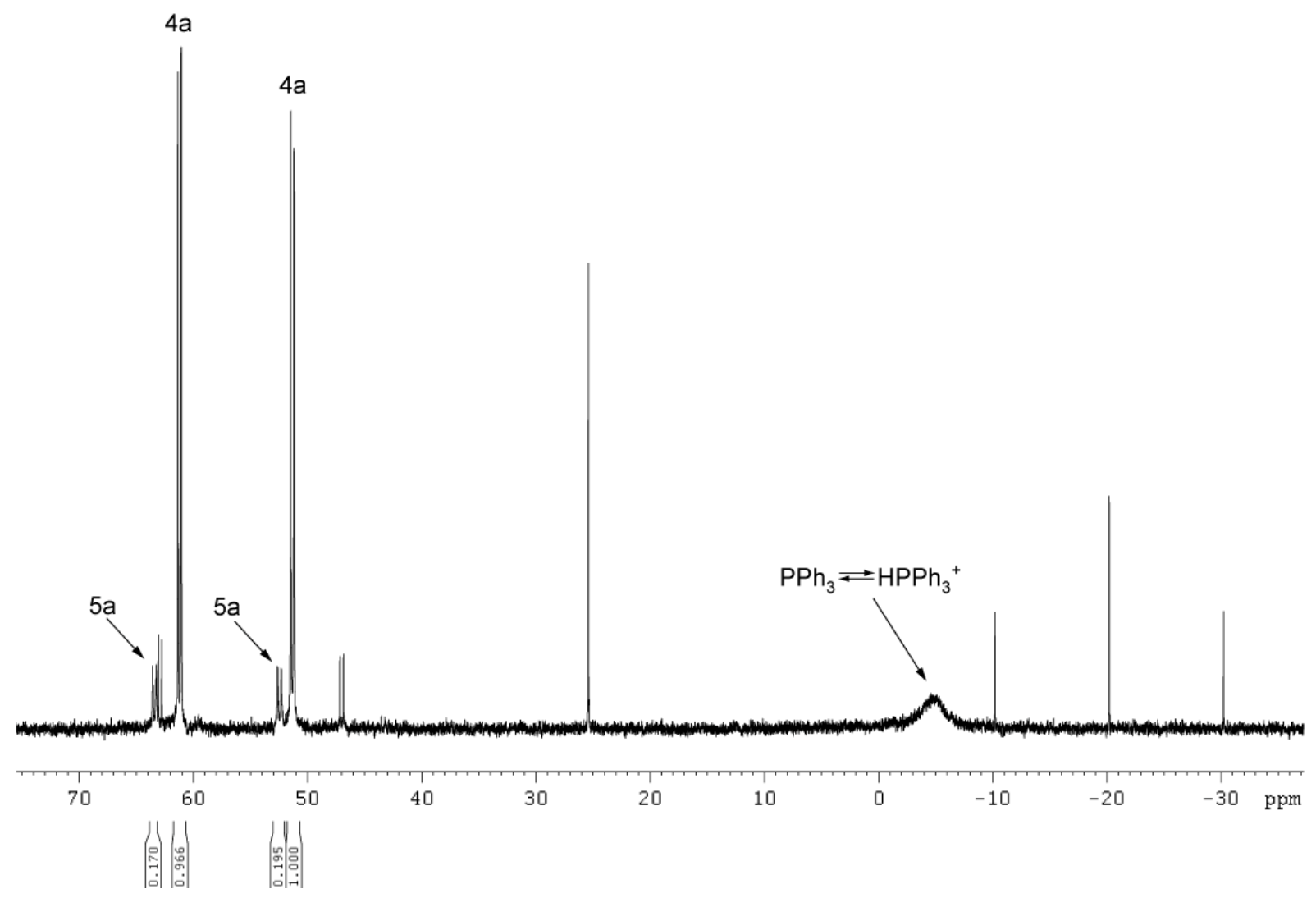

Table 2. Calculated $\mathrm{p} K_{a}$ values for $\mathbf{4 a}$ on the pseudo-aqueous scale, using eqs $2-4$ and the approximations from eqs 5 and 6.

\begin{tabular}{|c|c|c|c|}
\hline & \multicolumn{2}{|c|}{$[\mathbf{5 a}] /[\mathbf{4 a}]$} & \\
\cline { 2 - 4 } & $\begin{array}{c}\text { Fourier: } \\
0.155\end{array}$ & $\begin{array}{c}\text { Lorentzian: } \\
0.175\end{array}$ & $\begin{array}{c}\text { Approx. } \\
\text { eq 6 }\end{array}$ \\
\hline $\begin{array}{c}{\left[\mathrm{HPPh}_{3}{ }^{+}\right] /\left[\mathrm{PPh}_{3}\right]} \\
\text { Integration: } 0.168\end{array}$ & 4.32 & 4.26 & 4.28 \\
\hline $\begin{array}{c}\text { Fourier and Lorentzian: } \\
\delta_{\text {eq }}:-5.10\end{array}$ & 4.96 & 4.91 & 5.57 \\
\hline $\begin{array}{c}\text { Approximation } \\
\text { eq 5 }\end{array}$ & 4.35 & 4.24 & \\
\hline
\end{tabular}


Catalytic Michael Addition Reactions. A solution of $\left[\mathrm{RuCl}_{2}(\mathrm{PNNP})\right](30 \mathrm{mg}, 36$ $\mu \mathrm{mol}, 5 \mathrm{~mol}-\%)$ and $\left(\mathrm{Et}_{3} \mathrm{O}\right) \mathrm{PF}_{6}(19 \mathrm{mg}, 76 \mu \mathrm{mol}, 2$ equiv $10 \mathrm{~mol}-\%)$ in $\mathrm{CH}_{2} \mathrm{Cl}_{2}(2 \mathrm{ml})$ was stirred for $12 \mathrm{~h}$. Then, the catalyst solution was added to 2-tert-butoxycarbonylcyclopentanone (2) (133 mg, $0.72 \mathrm{mmol})$ and decane $(100 \mathrm{mg}, 0.70 \mathrm{mmol})$. The solution was stirred for 2 min before methyl vinyl ketone (6) (71.0 $\mu 1,86.4 \mu \mathrm{mol}, 1.2$ equiv) was added. The reaction mixture was stirred for $24 \mathrm{~h}$ at room temperature and then analyzed by quantitative GC by using decane as internal standard. The conversion of 2 was $97 \%$ and the yield of 7 94\%. The product 7 was purified by chromatography ( $\mathbf{R}_{\mathrm{f}}$ (Silicagel 60, hexane $/$ PrOH 4:1) = 0.2) and characterized by H NMR spectroscopy and GC-MS. ${ }^{1} \mathbf{H}$ NMR $\left(200 \mathrm{MHz}, \mathrm{CDCl}_{3}\right): 2.88-2.20\left(m, 6 \mathrm{H}, \mathrm{CH}_{2}\right), 2.17\left(s, 3 \mathrm{H}, \mathrm{CH}_{3}\right), 2.11-1.80\left(m, 4 \mathrm{H}, \mathrm{CH}_{2}\right)$, $1.47\left(s, 9 \mathrm{H},{ }^{t} \mathrm{Bu}\right) . \mathbf{G C}-\mathbf{M S}\left(50^{\circ} \mathrm{C}(3 \mathrm{~min})-250^{\circ} \mathrm{C}(10 \mathrm{~min})\right.$ at $\left.8^{\circ} \mathrm{C} / \mathrm{min}\right): \mathrm{t}_{\mathrm{R}}=19.69 \mathrm{~min}, \mathrm{~m} / \mathrm{z}$ $198.00\left(60,\left[\mathrm{M}^{+}-\mathrm{C}_{4} \mathrm{H}_{8}\right]\right)$. The enantioselectivity was $79 \%$ ee $(R)$ as determined by HPLC analysis on Diacel Chiralpack AS column $\left(0.44 \mathrm{~mL} / \mathrm{min}\right.$, hexane/ ${ }^{\mathrm{P}} \mathrm{PrOH} 99: 1,10 \mu \mathrm{L} ; \mathrm{t}_{\mathrm{R}}=31.5$ min, major; 36.7 min, minor). The absolute configuration was assigned by comparison of HPLC data and optical rotation to reported values. ${ }^{10}[\alpha]_{\mathrm{D}}^{25} @ 79 \%$ ee $=+5.954(5)\left(\mathrm{CHCl}_{3}\right.$, $c=2.7)$.

\section{Stoichiometric Reactions}

Reaction of $\mathbf{4 a}$ with Methyl Vinyl Ketone. The reaction was carried out in a Schlenk tube under argon. Complex 4a was prepared in situ by activation of $\left[\mathrm{RuCl}_{2}(\mathrm{PNNP})\right](30.0 \mathrm{mg}, 36$ $\mu \mathrm{mol})$ with $\left(\mathrm{Et}_{3} \mathrm{O}\right) \mathrm{PF}_{6}(17.9 \mathrm{mg}, 72 \mu \mathrm{mol}, 2.0$ equiv $)$ in $\mathrm{CD}_{2} \mathrm{Cl}_{2}(1 \mathrm{~mL})$, stirring the solution for $18 \mathrm{~h}$, and adding 2-tert-butoxycarbonylcyclopentanone (2) (6.7 mg, 36 umol, 1.0 equiv) and decane $(5.0 \mathrm{mg}, 35 \mu \mathrm{mol})$. After stirring for $1 \mathrm{~h}$, methyl vinyl ketone (4 $\mu \mathrm{L}, 49 \mu \mathrm{mol}, 1.3$ equiv) was added. The reaction was monitored by GC analysis after quenching the samples 
(30 $\mu \mathrm{L})$ with $\mathrm{Et}_{4} \mathrm{NCl}(\sim 10 \mathrm{mg})$. After a reaction time of $4 \mathrm{~h}$, the conversion of 2 and the yield of 7 were 98 and $93 \%$, respectively. The enantiomeric excess of 7 was $90 \%$ ee (by HPLC). ${ }^{1} \mathrm{H}$ NMR, GC-MS, and HPLC were identical to those of the product of catalysis.

Reaction of $\mathbf{5 a}$ with Methyl Vinyl Ketone: Isolated enolato complex 5a (57 mg, 52 $\mu \mathrm{mol})$ was dissolved in $\mathrm{CD}_{2} \mathrm{Cl}_{2}(1 \mathrm{~mL})$ with methyl vinyl ketone (4.3 $\mu \mathrm{L}, 52 \mu \mathrm{mol}, 1.0$ equiv). The solution was transferred in a NMR tube and monitored by NMR spectroscopy. No conversion was detected after $48 \mathrm{~h}$.

Reaction of 5a / $\mathrm{Et}_{3} \mathrm{NH}^{+}$with Methyl Vinyl Ketone: $\left[\mathrm{RuCl}_{2}(\mathrm{PNNP})\right]$ (100 mg, 0.12 mmol) and $\left(\mathrm{Et}_{3} \mathrm{O}\right) \mathrm{PF}_{6}\left(62.7 \mathrm{mg}, 0.25 \mathrm{mmol}, 2.1\right.$ equiv) were dissolved in $\mathrm{CD}_{2} \mathrm{Cl}_{2}(1 \mathrm{~mL})$, and the solution was stirred for $6 \mathrm{~h}$, after which 2-tert-butoxycarbonylcyclopentanone (2) (26.6 mg, 0.14 mmol, 1.2 equiv) was added. After stirring the solution for additional $6 \mathrm{~h}, \mathrm{NEt}_{3}(24$ $\mathrm{mg}, 0.24 \mathrm{mmol}, 2.0$ equiv) and then methyl vinyl ketone (12.2 mg, $0.17 \mathrm{mmol}, 1.4$ equiv) were added, and the solution was transferred in a NMR tube and monitored by NMR spectroscopy. No conversion was detected after $48 \mathrm{~h}$.

Reaction of $\mathbf{5 a}$ with $\left(\mathrm{HNEt}_{3}\right) \mathrm{BPh}_{4}$ and Methyl Vinyl Ketone: Enolato complex 5a (19 $\mathrm{mg}, 18 \mu \mathrm{mol})$ was dissolved in $\mathrm{CD}_{2} \mathrm{Cl}_{2}(1 \mathrm{~mL})$. $\left(\mathrm{HNEt}_{3}\right) \mathrm{BPh}_{4}(7 \mathrm{mg}, 18 \mu \mathrm{mol}, 1.0$ equiv) and methyl vinyl ketone $(1.5 \mu \mathrm{L}, 18 \mu \mathrm{mol}, 1.0$ equiv) were added, the solution was transferred in a NMR tube and monitored by NMR spectroscopy. No conversion was detected after $48 \mathrm{~h}$.

X-ray Structure of 5a. All attempts to crystallize the enantiomerically pure complex $(S, S)$-5a failed. Red crystals of (rac)-5a were grown by slow diffusion of pentane into $\mathrm{CH}_{2} \mathrm{Cl}_{2}$. Crystal data for $\mathrm{C}_{54} \mathrm{H}_{55} \mathrm{Cl}_{2} \mathrm{~F}_{6} \mathrm{~N}_{2} \mathrm{O}_{3} \mathrm{P}_{3} \mathrm{Ru}$ : prism $(0.80 \times 0.42 \times 0.23 \mathrm{~mm})$, triclinic, $\mathrm{P}-1$, cell dimensions (200 K) $a=14.9279(11), b=16.6872(12), c=23.5871(17) \AA, \alpha=78.0510(10), \beta$ $=74.0360(10), \gamma=79.2880^{\circ}$ and $V=5474.5(7) \AA^{3}$ with $Z=2, D_{c}=1.433 \mathrm{Mg} / \mathrm{m}^{3}, \mu=0.549$ $\mathrm{mm}^{-1}$ (Mo $\mathrm{K}_{\alpha}$, graphite monochromated), $\lambda=0.71073 \AA, F(000)=2420$. The data were collected at $200 \mathrm{~K}$ on a Bruker AXS SMART APEX platform in the $\theta$ range $1.72-26.37^{\circ}$. The 
structure was solved with SHELXTL using direct methods. The asymmetric unit contains two essentially identical, crystallographically independent 5a molecules, two crystallographically independent $\left[\mathrm{PF}_{6}\right]^{-}$anions, and four disordered $\mathrm{CH}_{2} \mathrm{Cl}_{2}$ molecules at partial occupation (approx. total of 2.7). Of the 49537 measured reflections with index ranges $-18 \leq h \leq 18,-20$ $\leq k \leq 20,-29 \leq l \leq 29,22319$ independent reflections were used in the refinement (full-matrix least squares on $F^{2}$ with anisotropic displacement parameters for all non-H atoms (except $\mathrm{C}(4 \mathrm{~S})$ of a disordered $\mathrm{CH}_{2} \mathrm{Cl}_{2}$ molecule). Hydrogen atoms were introduced at calculated positions and refined with the riding model and individual isotropic thermal parameters for each group. Final residuals were $R_{1}=0.0497$ (for 19304 reflections with $I>2 \sigma(I)$ ), $R_{1}=$ 0.0573 (all data), $w R_{2}=0.1418$ (all data), $\mathrm{GOF}=1.041$. Max. and min. difference peaks were +2.25 and $-0.73 \mathrm{e}^{-3}$, the largest and mean $\Delta / \sigma=0.001$ and 0.000 .

$\mathbf{X}$-ray Structure of $\mathbf{5 b}$. All attempts to crystallize the enantiomerically pure complex $(S, S)$-5b failed. Red crystals of ( $\mathrm{rac})$-5b were grown by slow diffusion of hexane into $\mathrm{CH}_{2} \mathrm{Cl}_{2}$. Crystal data for $\mathrm{C}_{61} \mathrm{H}_{52} \mathrm{Cl}_{6} \mathrm{~F}_{6} \mathrm{~N}_{3} \mathrm{O}_{2} \mathrm{P}_{3} \mathrm{Ru}$ : prism $(0.24 \times 0.21 \times 0.14 \mathrm{~mm})$, triclinic, $\mathrm{P}-1$, cell

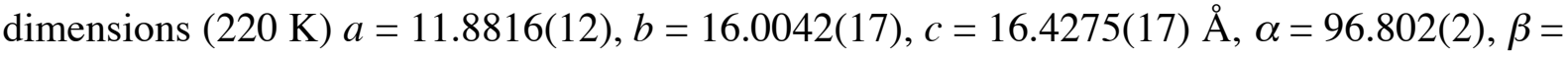
97.407(2), $\gamma=93.830(2)^{\circ}$ and $V=3065.2(5) \AA^{3}$ with $Z=2, D_{c}=1.495 \mathrm{Mg} / \mathrm{m}^{3}, \mu=0.659 \mathrm{~mm}^{-1}$ (Mo $\mathrm{K}_{\alpha}$, graphite monochromated), $\lambda=0.71073 \AA$, $F(000)=1400$. The data were collected at $220 \mathrm{~K}$ on a Bruker AXS SMART APEX platform in the $\theta$ range $1.29-26.37^{\circ}$. The structure was solved with SHELXTL using direct methods. The asymmetric unit contains one 5b cation, one $\left[\mathrm{PF}_{6}\right]^{-}$anion, and three disordered $\mathrm{CH}_{2} \mathrm{Cl}_{2}$ molecules. The six-membered ring of the lactam has an envelope conformation with the out-of-plane atom, C(49), disordered over two positions at 87:13 occupancy (only the major conformer is shown in the ORTEP plot). Of the 25128 measured reflections with index ranges $-14 \leq h \leq 14,-20 \leq k \leq 19,-20 \leq l \leq 20$, 12434 independent reflections were used in the refinement (full-matrix least squares on $F^{2}$ with anisotropic displacement parameters for all non-disordered, non-H atoms. Hydrogen 
atoms (of non-disordered atoms) were introduced at calculated positions and refined with the riding model and individual isotropic thermal parameters for each group. Final residuals were $R_{1}=0.0620$ (for 9525 reflections with $I>2 \sigma(I)$ ), $R_{1}=0.0848$ (all data), $\mathrm{w} R_{2}=0.1924$ (all data), GOF $=1.058$. Max. and min. difference peaks were +1.59 and $-1.03 \mathrm{e}^{-3}$, the largest and mean $\Delta / \sigma=0.001$ and 0.000 .

\section{References}

(1) Gao, J. X.; Ikariya, T.; Noyori, R. Organometallics 1996, 15, 1087.

(2) For a discussion of acid-base equilibria in non-aqueous solvents and $\mathrm{p} K_{a}$-determination by reaction with phosphines, see: Kristjansdottir, S. S.; Norton, J. R. In Transition Metal Hydrides; Dedieu, A., Ed.; VCH: Weinheim, 1992, pp 309-359.

(3) (a) Streuli, C. A. Anal. Chem. 1960, 32, 985-987. (b) Pestovsky, O.; Shuff, A.; Bakac, A. Organometallics ASAP article, 4.26.2006, DOI: 10.1021/om060221z.

(4) Perrin, D. D. In Dissociation Constants of Organic Bases in Aqueous Solution: Supplement, IUPAC: London, 1972.

(5) Arnett, E. M.; Wu, C. Y. J. Am. Chem. Soc. 1960, 82, 4999-5000.

(6) Pearson, R. G.; Dillon, R. L. J. Am. Chem. Soc. 1953, 75, 2439-2443.

(7) Guthrie, J. P.; Cossar, J.; Klym, A. J. Am. Chem. Soc. 1984, 106, 1351-1360.

(8) (a) Levi, A.; Modena, G.; Scorrano, G. J. Am. Chem. Soc. 1974, 96, 6585-6588. (b) Jensen, J. L.; Thibeault, A. T. J. Org. Chem. 1977, 42, 2168-2170.

(9) The inverse-gated proton-decoupling suppresses the phosphorus signal enhancement by nuclear Overhauser effects from spatially close hydrogen atoms. Therefore, accurate integration values of phosphorus atoms in different chemical environments are possible with this method. See, for example: Braun, S.; Kalinowski, H.-O.; Berger, S. 150 and More Basic NMR Experiments, $2^{\text {nd }}$ expanded ed., Wiley: New York, 1998, p. 123. 
(10) Hamashima, Y.; Hotta, D.; Sodeoka, M. J. Am. Chem. Soc. 2002, 124, 11240-11241. 